\title{
WHO IS SEATED ON HIS LAP? \\ SITTING ON A MAN'S LAP IN THE ANCIENT EGYPTIAN SCENES AND STATUARY
}

\author{
WALAA MOHAMED ABDELHAKIM \\ FACULTY OF TOURISM AND HOTELS, MINIA UNIVERSITY, EGYPT
}

\begin{abstract}
According to the Oxford dictionary the lap is defined as the flat area between the waist and the knees of a seated individual and used to hold a child or anything else. In ancient Egypt the attitude of lap sitting expresses in particular from the earliest times the relation between two individuals; an adult woman and a child, the mother the seated individual and the child sitting on her lap. The divine model for this attitude relation is the mother goddess Isis in her image holding her son the child god Horus on her lap. Another distinguished relation was also expressed in the attitude of lap sitting that also gathers between two individuals but this time between an adult man the seated one and another individual sitting on his lap. This relation is the focus of the research that deals with the motif of sitting on the lap of a man in ancient Egypt. Through the descriptive and analytical methodology for all the scenes and statuary that depict the motif, the research will conclude certain points: the main classifications for the scenes and statuary depicting the motif of lap sitting according to the identity of the man, upon whose lap another individual is seated; the type of relation between the two individuals depicted in the motif; and the differences and characteristics of the depicted ways of sitting on a man's lap according to the type of relation between the two depicted individuals in the motif.
\end{abstract}

KEYWORDS: sitting, lap, child, tutor, prince

\section{INTRODUCTION}

The motif of lap sitting was traditionally represented in the ancient Egyptian art since the Old Kingdom and was so popular during the Late period as a great number of sacred bronze statuettes for goddess Isis, the most famous nurturing deity, with her son Horus sitting on her lap were 
produced. ${ }^{1}$ The earliest representation for the motif of lap sitting in the Old Kingdom period was found in statuary not scenes. It depicts the image of a young individual sitting on a woman's lap. ${ }^{2}$ It is the $6^{\text {th }}$ Dynasty royal statuette of the young Pepy II as a miniature king seated sideways on the lap of his mother, Queen Ankhnesmeryra. ${ }^{3}$ Thus the earliest example for the motif of female lap sitting recalls the divine relation between the nurturing goddess and her son.

In the ancient Egyptian private scenes and statuary the motif of a child sitting on the lap of one of his parents is rare in contrast to the frequent depictions of a child standing or sitting, under or beside his parent's chair, as the motif of lap sitting was particularly reserved for the individuals, who occupied the office of the nurse and tutor. ${ }^{4}$

The image of the nurse was referred to in Gardiner's Sign-list $(B 5,6)$ that represents a kneeling or seated woman with a child sitting on her lap. These signs were used as determinatives in terms related to nursing;

\section{5 ' woman suckling child Det. 'suckle' in ${ }^{1}$ Exx. Dyn. XII, BH. i. 25, 79; Dyn. XVIII, D.el B. 53. \\ 6 漹 1 woman seated on chair Det. 'nurse' in 으 rmn 'nurse', 'rear'. with child on lap $\quad{ }^{1}$ Exx. L. D. iii. $53 ;$ D.elB. 101.}

Such images for the nursing woman with a child on the lap was usually included in the context of daily life scenes, like the representations of a

\footnotetext{
${ }^{1}$ Models for the Late Period bronze statuettes of Isis and Horus are found in the British Museum (EA 67186), and at Vienna (Agyptisch-Orientalische Sammlung 8564) (see Jennifer Witts, The role of magic and medicine in the lives of ancient Egyptian women and their children, MPhil Thesis, (University of Stellenbosch, 2005), 132, Figs 3.1.7 and 3.1.8); The representation of the nurturing deity, goddess Isis, with her son Horus sitting on her lap extended throughout the Greek and Roman periods, for examples from the temple of Isis at Philae and others in Minor Arts see Marwa Elkady, Manal Mahmoud and Nermin Gad , "Wet Nurse in art in Graeco-Roman Egypt", in Journal of the Faculty of Tourism and Hotels, Alexandria University, Vol. 16, Issue 2, (2019), 33, 38, 39.

${ }^{2}$ Catharine Hershey Roehrig, the Eighteenth Dynasty titles royal nurse (mnt nswt), royal tutor (mn' nswt), and foster brother/sister of the Lord of the Two Lands (sn/snt mn' $n n b$ t3wy), Ph.D., (Berkeley: University of California, 1990), 2; Richard H. Wilkinson, Reading Egyptian Art, (London: Thames and Hudson, 1992), 33.

${ }^{3}$ The statuette is made of alabaster and dates back to the reign of king Pepy I, the husband of Queen Ankhnesmeryra. Its provenance is unknown and is now preserved in Brooklyn Museum of Art (No. 39.119). (Rehab Elsharnouby, "Statue Attributes of the Old Kingdom Queens", in International Journal of Heritage, Tourism and Hospitality Vol.12, No. 2/2, (2018), 107)

${ }^{4}$ Boyo Ockinga and Susanne Binder, "Fragments of an Amarna-age Stele in the Teti Pyramid Cemetery North", in Études et Travaux XXVI, (2013),512.
} 
peasant woman with a child beneath a tree, and a nursing woman seated with singers and musicians. ${ }^{5}$

The motif of a child or a young individual sitting on the lap of his tutor did not appear in scenes nor statuary till the mid of the $18^{\text {th }}$ Dynasty in the New Kingdom period, ${ }^{6}$ during which certain innovations adapted to the motif of lap sitting particularly during the Amarna period in the reign of king Akhenaten. The research will introduce such innovated representations for the motif of lap sitting as one of the classifications for the motif of sitting on a man's lap that is the main subject of the study. ${ }^{7}$

\section{OBJECTIVES OF THE STUDY}

- Identifying scenes and statues depicting the attitude of sitting on a man's lap.

- Classifying the scenes and statuary depicting the motif of lap sitting according to the identity of the man, upon whose lap another individual is seated, is he a parent, a tutor, a husband, or a god?

- Determining the type of relation between the individuals depicted in the motif of sitting on a man's lap: a father and his child, a tutor and his student, a man and his wife, or a god and his divine wife.

- Indicating the differences and characteristics of the depicted ways of sitting on a man's lap, are they the same, or differ according to the type of relation between the two depicted individuals?

\section{Methodology}

The research applies the descriptive and analytical study of the representations related to the motif of sitting on a man's lap in the ancient Egyptian scenes and statuary either royal or private.

\footnotetext{
${ }^{5}$ Z. Hawass, and M. Maher Taha, Le tombeau de Menna, (Cairo, 2002), Pl. 26; Abd El Ghafar Shadeed, Maqaber Bani Hassan fi Masr Al Wasta, First Edition, (Cairo: Al Markez Al Qawme lltargma, 2016), 51; N. DE G. DAVIES, The Tomb of Neferhotep at Thebes II, (New York, 1933), Pl. I.

${ }^{6}$ Catharine Hershey Roehrig, the Eighteenth Dynasty titles, 3.

${ }^{7}$ The motif that is discussed in the study is for two individuals; a seated man with another individual either male, or female sitting on his lap. There is another different motif for a kneeling worshipper with a sacred symbol or the image of a deity on his lap. The carved figure of a kneeling man holding a symbolic image on the lap was first introduced in the New Kingdom statues of the architect Senenmut. See Bernard V. Bothmer, "Private Sculpture of Dynasty XVIII in Brooklyn", in The Brooklyn Museum Annual 8, (1966), 62; https://www.brooklynmuseum.org/opencollection/objects/3759. Later examples for the motif usually show the image of the deity standing inside a small shrine.
} 


\section{DiscusSiOn AND RESULTS}

\section{SitTing ON FATHER'S LAP IN SCENES}

Though the representation of children with their parents was so popular on non-royal monuments from the Old Kingdom period onwards, the image of the child sitting on the lap of an adult is rare. ${ }^{8}$ This image was used as a determinative in the ancient Egyptian names expressing young and child

that is indicated in two signs in Gardiner's sign list: (A 17)

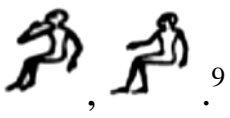

The motif of sitting on a father's lap was found on a limestone funerary stela dates back to the Middle Kingdom period, $12^{\text {th }}$ Dynasty, and belongs to a draftsman and a chief of scribes during the Middle Kingdom called Dedusobek. The stela was discovered in the northern necropolis at Abydos and is now displayed on the ground floor of the Egyptian Museum (Cairo, CG $20596=$ JE 21905) $\left(\right.$ Fig. 1). ${ }^{10}$

The stela shows Dedusobek sitting on a low backed chair with his child daughter on his lap facing forward in front of a small offering table. The girl is identified as the justified Rensenebsu and is shown with a back pigtail that was a fashion for girl dancers. ${ }^{11}$ Her skin should have been painted pale cream, the color of female, but its shade is even darker than her father's. She seems to smell a flower with her left hand, while her right arm is reclined on her father's right arm, who embraces her from the back at her waist. ${ }^{12}$

\footnotetext{
${ }^{8}$ Boyo Ockinga and Susanne Binder, Fragments of an Amarna-age Stele in the Teti Pyramid Cemetery North, 511.

${ }^{9}$ For the sign of the child sitting on an adult lap with a finger held to his mouth see Barry Kemp, 100 Hieroglyphs: Think Like An Egyptian, (Granta Books, 2012), 78.

${ }^{10}$ Danijela Stefanović, "The Stela of Dedusobek. (Cairo, CG 20596)", in Zeitschrift für Ägyptische Sprache und Altertumskunde, Volume 136 Issue 1, (2009), 84; Adela Oppenheim, Dorothea Arnold, Dieter Arnold, and Kei Yamamoto, Ancient Egypt Transformed the Middle Kingdom, (New York: the Metropolitan Museum of Art, 2015), 191, Fig. 91.

${ }^{11}$ Erika Feucht, "Childhood", in Donald B. Redford (Hrsg.), The Oxford Encyclopedia of Ancient Egypt, Band 1, (Oxford 2001), 262.

12 Kasia Szpakowska, Daily Life in Ancient Egypt, (Wiley, 2007), 50; The Egyptian Museum, Splendors of ancient Egypt, (Cairo, Booth-Clibborn Editions, 1996), 70.
} 


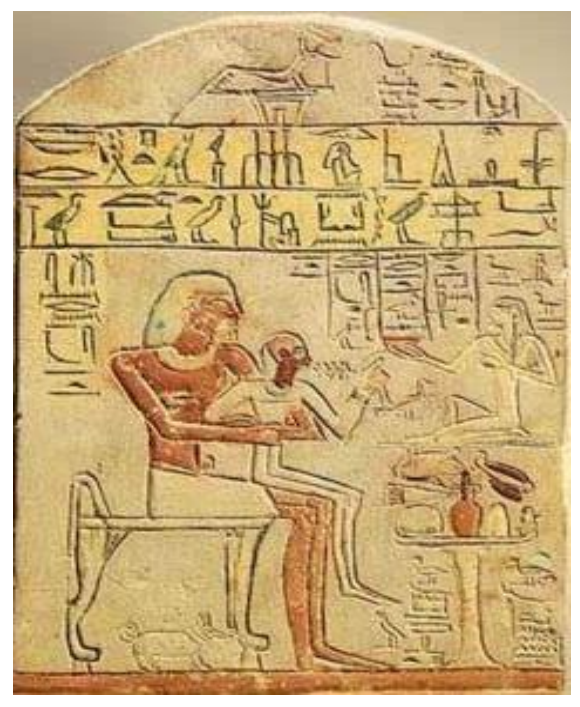

Fig. 1: The scribe Dedusobek with his daughter seated on his lap

(After Galal Ali Hassaan, Mechanical Engineering in Ancient Egypt, Part II: Jewellery Industry (Pectorals), in International Journal of Recent Engineering Science (IJRES), volume 3 Issue 1, (2016), 24, Fig. 5)

There is another example for the motif of sitting on a father's lap in scenes dates back to the New Kingdom period, $18^{\text {th }}$ Dynasty. The motif is depicted on the lower half of a private limestone offering stela that is recently preserved in the Egyptian Museum at Cairo (JE 18924). It belongs to a man called Thener, who was an outline draftsman during the reign of king Thutmose IV/ Amenhotep III. The lower scene of the stela that includes the motif of lap sitting shows Thener sitting with his family at an offering table. On his lap is seated sideways one of his daughters named Sekhmet-nefer(t). His left arm surrounds her at the left shoulder like a scarf crossing tilted through her chest and resting at her waist, while his right arm is rest on his left wrist. His little daughter appears nude with a massive side lock of hair and puts her right hand on her father's chest. Her finger appears to be extended as a gesture for protection to avert any evil (Fig. 2). ${ }^{13}$

The inscription accompanied the scene gives the name of Thener, his office, and the names of his wife and daughters. Concerning the name and office of Thener inscribed in front of his face; Tnr "the Outline Draftsman Thener", while the name of the child daughter

\footnotetext{
${ }^{13}$ Dina Metawi, "The Stela of the Outline Draftsman Tnr and His Family (Cairo Museum JE 18924)", in Journal of Near Eastern Studies 77, no. 1 (2018), 31, 32, 34, 35, Figs. 1, 4.
} 
on his lap, Sekhmet-nfr(t), is preceded by the expression "His beloved daughter" and written to the left of her head;

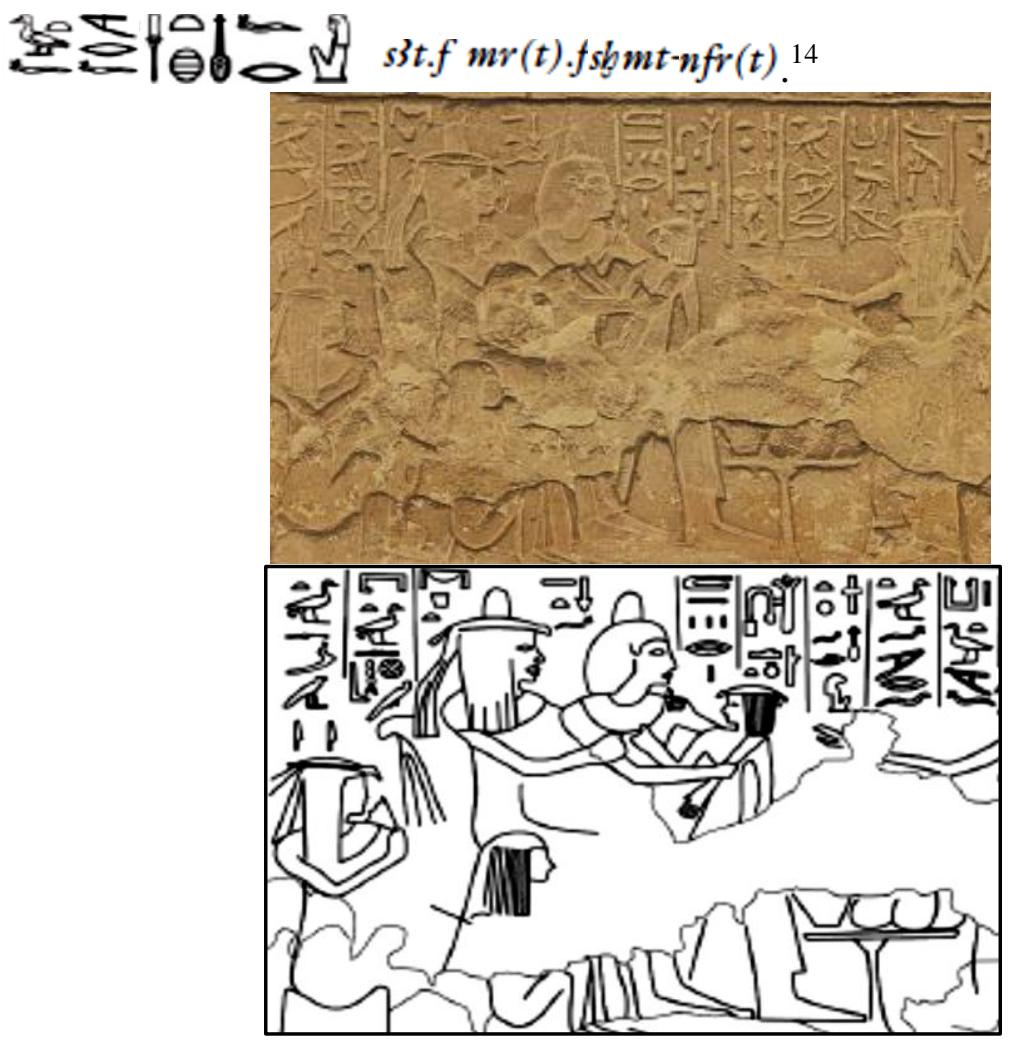

Fig. 2: The outline draftsman Thener with his little daughter on his lap

\section{(After Dina Metawi, The Stela of the Outline Draftsman Tnr and His} Family, 32, 35, Figs. 1, 4)

Though the attitude of sitting on a father's lap was early mentioned in the Pyramid Texts (PT $553 \S 1367 \mathrm{c}$ ), ${ }^{15}$ there is only one royal example for the motif of sitting on a father's lap in statuary. It dates back to the New Kingdom period and belongs to Siptah, who was the penultimate ruler of the $19^{\text {th }}$ Dynasty. The statue is made of limestone and is badly damaged. It is now preserved in Munich Glyptothek no. 122. It shows Siptah as a small

\footnotetext{
${ }^{14}$ The office of Thener as an outline draftsman was well known since the Old Kingdom period. Its main task to prepare any area whatever its material with the outline sketches that would be later engraved by the sculptors to produce an object, design, or inscription. (Ibid., 36-37)

dj hms.f hr jst wrt hr mntj jt.f hnt jrtj

15 dj hms NN hr jst wrt hr mntj jt.f gbb "He seats on the great throne on his father's lap". James P. Allen, A New Concordance of the Pyramid Texts, Volume I, (Providence: Brown University, 2013).
} 
figure, whose head is completely destroyed, sitting on the lap of another larger male figure, of which only traces remain; the legs in front of the throne decorated with the symbol of the unification of the two lands "sm3 $t 3 w y^{\prime \prime}$, and the arm resting on the back of Siptah (Fig. 3). ${ }^{16}$

Siptah was not the crown prince. He ascended to the throne as a child of ten or eleven years old after the death of his Predecessor Seti II. ${ }^{17} \mathrm{He}$ appears in the statue with a crossed right arm on the chest, holding a scepter and a flagellum in his right hand, wearing a short pleated kilt and a pair of sandals, and resting his feet on a high pedestal carved with erased cartouches and a double pair of foreign captives. In front of the kilt on a band was partly preserved two small cartouches written in one vertical line giving the royal names of king Siptah adapted after the second year of his

reign: ${ }^{18}$

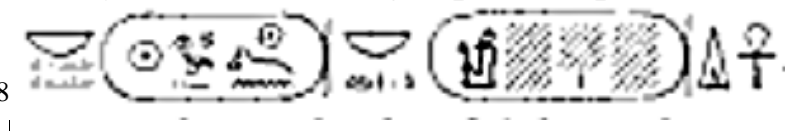

nb t3wy 3h-n-R ${ }^{\varsigma}-s t p-n-R^{\varsigma} n b$ t3wy [Mrj-n-]Pth-[s3-Pth] di ${ }^{\varsigma} n h$

"Lord of the Two Lands the Spirit of Ra, the Chosen One of Ra, Lord of the Two Lands [the Beloved of ]Ptah, [the Son of Ptah]giving life".

Concerning the damaged larger figure, upon whose lap Siptah is seated, is most probably belongs to his father, but his exact identity is uncertain and here are the different opinions related to the identity of the figure in general:

- He is Amenmesse the father of Siptah. As both of Amenmesse and Siptah spent their youth in Akhmim and were specifically excluded from Ramesses III's Medinet Habu procession of statues of the ancestral kings. Thus Amenmesse and Siptah seem to be interrelated in being regarded as illegitimate rulers and were most probably a father and his son. ${ }^{19}$

- He is Seti II the father of Siptah and his Predecessor.

- The figure is for the second royal wife of king Seti II and the stepmother of Siptah, Queen Twosre, whom he was placed under her guidance for being a child king and succeeded him on the throne to be the last ruler of the $19^{\text {th }}$ Dynasty. ${ }^{20}$ In the statue she is suggested to

\footnotetext{
${ }^{16}$ J. Von Beckerath, Queen Twosre as Guardian of Siptah, in JEA 48, (1962), Pl. III.

${ }^{17}$ Jürgen von Beckerath, Chronologie des Pharaonischen Ägypten, 201.

${ }^{18}$ J. Von Beckerath, Queen Twosre as Guardian of Siptah, 73.

${ }^{19}$ Amenmesse was the fifth ruler of the $19^{\text {th }}$ Dynasty, possibly the son of Merneptah, and his successor on the throne was Seti II. Jürgen von Beckerath, Chronologie des Pharaonischen Ägypten, in MÄS 46 (Mainz: Philipp von Zabern, 1997), 201; Cyril Aldred, "The Parentage of King Siptah", in JEA 49, (1963), 41-60; J.E. Harris and E.F. Wente, An X-Ray Atlas of the Royal Mummies, (Chicago, 1980), 147.

${ }^{20}$ J. Von Beckerath, Queen Twosre as Guardian of Siptah, 73.
} 
represent herself as a male king, the same approach followed by the famous $18^{\text {th }}$ Dynasty female ruler Queen Hatshepsut to legitimate her ascension on the throne.

- He is not his father but the figure is for a high official acted as a chancellor for the child king Siptah named Bay, who was an important Asiatic official and rose to prominence and high office under king Seti II. ${ }^{21} \mathrm{He}$ had the permission and privilege to own a tomb for himself in the valley of the kings (KV13) that includes scenes for king Siptah and Queen Twosre. ${ }^{22}$
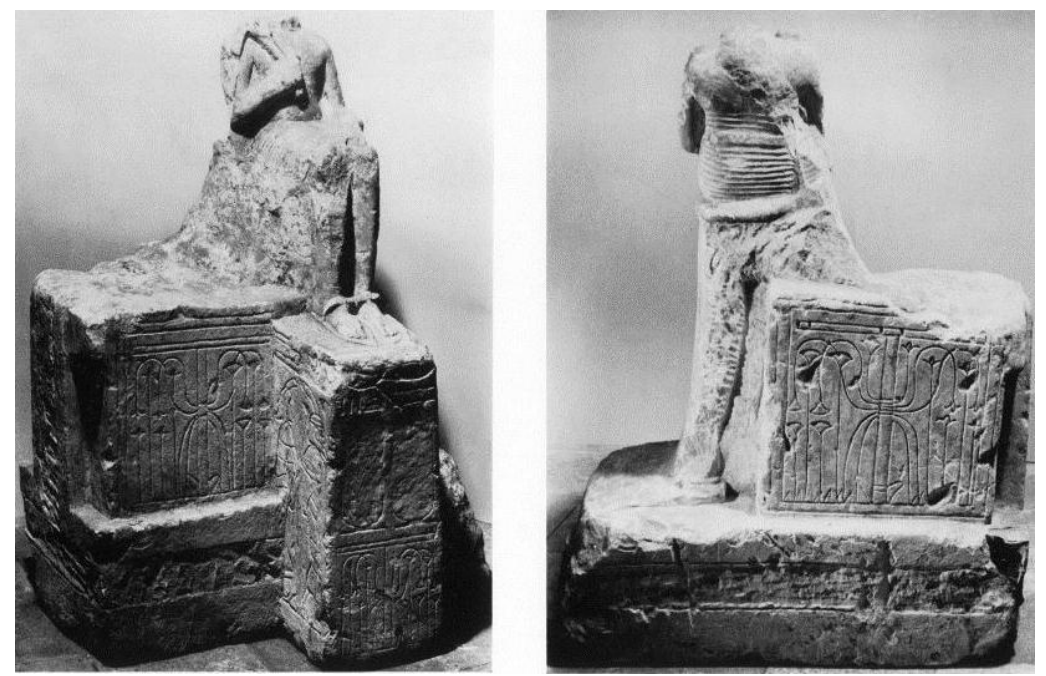

Fig. 3: The damaged royal group statue of king Siptah

(After J. Von Beckerath, Queen Twosre as Guardian of Siptah, Pl. III) SiTTING ON TUTOR'S LAP IN SCENES

The princes' relation with their parents was likely restricted. Their important formative years seem to have been spent in the company of male tutors and the high dignitary males in the other institutions such as priesthood and military affairs. Such particular kind of relation between a

\footnotetext{
${ }^{21}$ See Gae Callender, "The Cripple, the Queen \& the Man from the North", in KMT 17, No.1 (2006), 53.

${ }^{22}$ This opinion was not accepted as the statue her does not recall the $18^{\text {th }}$ Dynasty statues for a tutor and a royal child under his charge. Moreover it is unbelievable for a tutor or any official whatever was his rank and relation to the king to allow himself to be represented sitting on a throne. J. Von Beckerath, Queen Twosre as Guardian of Siptah, 73.
} 
member of the royal family and a public personality remained of great importance and value throughout life. ${ }^{23}$

Like the royal nurse the $18^{\text {th }}$ Dynasty high official occupied the positions of the royal tutor and guardian was occasionally shown seated with a young prince or princess or even a king in a miniature image sitting on his lap. $^{24}$

The earliest relief depiction for the motif of a seated tutor with a child on his lap is found in the center of the first register on the west wall of the $18^{\text {th }}$ Dynasty tomb of Pahery No. 3 at El Kab in Upper Egypt that shows the tutor Pahery sitting on a low back chair with a child on his lap (Fig. 4). ${ }^{25}$ This child is prince Wadjmose the son of king Thutmose III, ${ }^{26}$ who sits sideways in front-facing position on the lap of Pahery and appears with the traditional signs of childhood as indicated in Gardiner's sign list (A 17); being nude, and having a side braided plait of hair with its end rolled upwards ${ }^{27}$ His neck is decorated with an amulet, whose shape resembles the ancient Egyptian sign 6.28

As for his tutor Pahery he wears a long wig that reaches to his shoulders and is dressed in a long superfine vest with a loin cloth and a tunic. $\mathrm{He}$ places his right hand on the back of the head of the prince, while his left hand is resting on the prince's right hip. The inscription accompanied the motif $;^{29}$

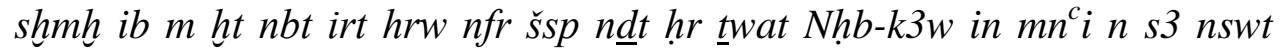
w3 $\underline{d-m s} h^{c}$ P3hri $m 3^{c}$ hrw

"Rejoicing the heart with everything, making holiday, receiving gifts, worshipping Nehebkau, by the tutor of prince Wadjmose, the ha-prince Paheri, deceased."

${ }^{23}$ Dominic Montserrat, Akhenaten: History, Fantasy and Ancient Egypt, (New York: Routledge, 2014), 34.

${ }^{24}$ Anne K. Capel, Glenn Markoe, and Betsy M. Bryan, Mistress of the House Mistress of Heaven Women in Ancient Egypt, (New York: Hudson Hills press, 1996), 18.

${ }^{25}$ J. J. Tylor and F. Ll. Griffith, The Tomb of Paheri at El Kab, (London: Egypt exploration fund, 1895), 18, Pl. IV.

${ }^{26}$ Wadjmose was possibly the crown prince of king Thutmose III till his precocious death in the early years of his father's reign. (Catharine Hershey Roehrig, the Eighteenth Dynasty titles, 23)

${ }^{27}$ The side braided plait of hair with its end rolled upwards was first exclusive for boys, but since the beginning of the $5^{\text {th }}$ Dynasty it was also for girls. (Erika Feucht, Childhood, 262)

${ }^{28}$ In Gardiners Sign-List (W 19) the sign represents a milk jug as carried in a net. Most probably the use of this sign as an amulet symbolizes the young age of the child and his necessary need to milk as the main food.

${ }^{29}$ J. J. Tylor and F. Ll. Griffith, The Tomb of Paheri at El Kab, 18. 


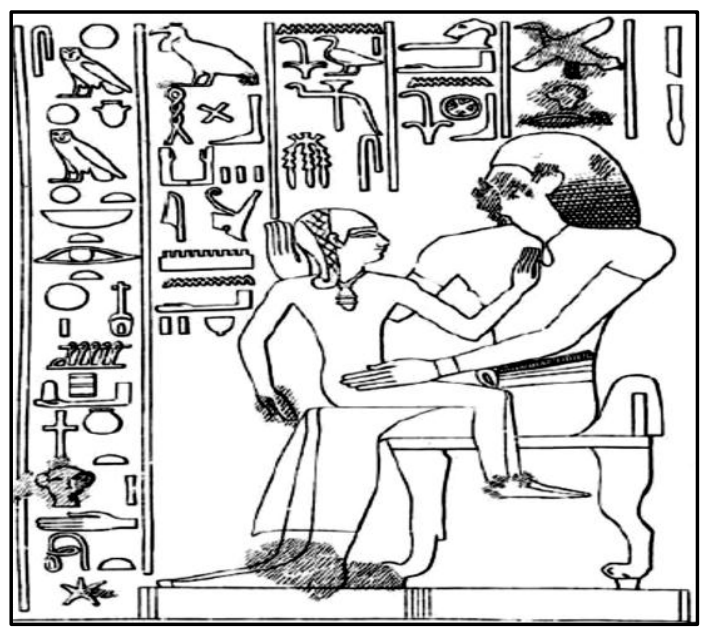

Fig. 4: Pahery with prince Wadjmose on his lap

(After J. J. Tylor and F. Ll. Griffith, The Tomb of Paheri at El Kab, Pl. IV)

A similar scene to that of the tutor Pahery, but is partially preserved, is found in the tomb of Min TT 109 on the southern wall of the transverse hall. It represents the tutor Min, who served as a mayor of Thinis $h 3 t y-{ }^{c} n$ tny and held a variety of dignitary titles during the reign of king Thuthmose III, with prince Amenhotep (the future king Amenhotep II) on his lap (Fig. 5). ${ }^{30}$ They are represented facing each other. Min places his right hand on the back of the head of the prince, while with his left hand he holds the prince's waist. The prince is shown nude with a thin side lock of hair. He gently touches the left shoulder of his tutor with his left hand. The preserved inscription accompanied the scene refers to Min as "it $m n^{c} y n s 3$ nswt Imn- htp the Father Tutor of Prince Amenhotep". ${ }^{31}$

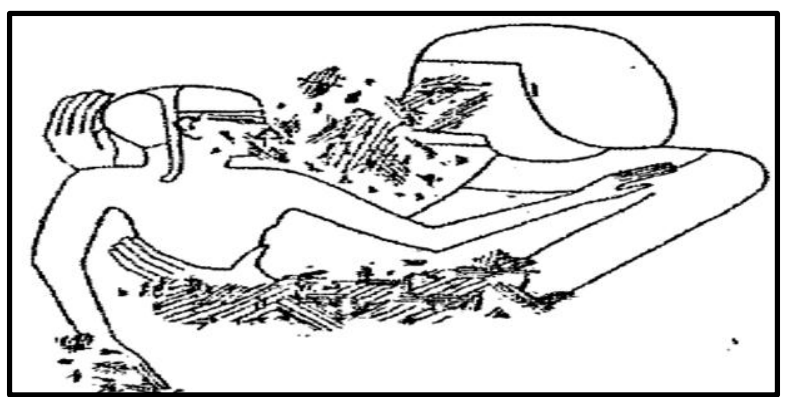

Fig. 5: Min with prince Amenhotep II on his lap

(After Catharine Hershey Roehrig, the Eighteenth Dynasty titles, Pl. 18)

\footnotetext{
${ }^{30}$ The tutor Min most probably died before the ascension of his nursling Amenhotep on the throne; P. Virey, Sept tombeaux thébains, in MMAF 2, , (1889), 368, Fig. 4.

${ }^{31}$ Catharine Hershey Roehrig, the Eighteenth Dynasty titles, 197, 289.
} 
A remarkable scene from the $18^{\text {th }}$ Dynasty TT 226 , time of king Amenhotep III, at Thebes in Sheikh Abd el-Qurna cemetery, on the back side of the central pillar to the north of the tomb's entrance, shows four princes sitting sideways in front-facing position on the lap of a tutor, whose name was unfortunately damaged but among his preserved titles are "Royal Scribe", "Overseer of the King's Tutors", and "Steward" (Fig. 6). ${ }^{32}$ The four princes are represented between the arms of their tutor nude with a red colored side lock of hair and jewelry. The first prince close to his tutor places his right arm on the right shoulder of his tutor as a characteristic gesture for expressing affection. There is a controversy between the archeologists over the identity of the four princes; whether they are the sons of king Thutmose IV or king Amenhotep III. Newberry believed that the four princes are the children of king Thutmose IV. The inscription above them is partially preserved. It identifies them as "the son of the king, whom he loves" and gives two names of the four princes;

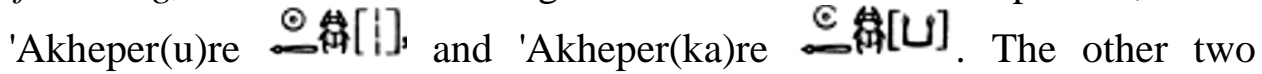
names are suggested to be Amenemhat, who died young and was buried in the tomb of his father at Biban El Muluf, and Amenhotep, who succeeded his father on the throne and became king Amenhotep III. ${ }^{33}$

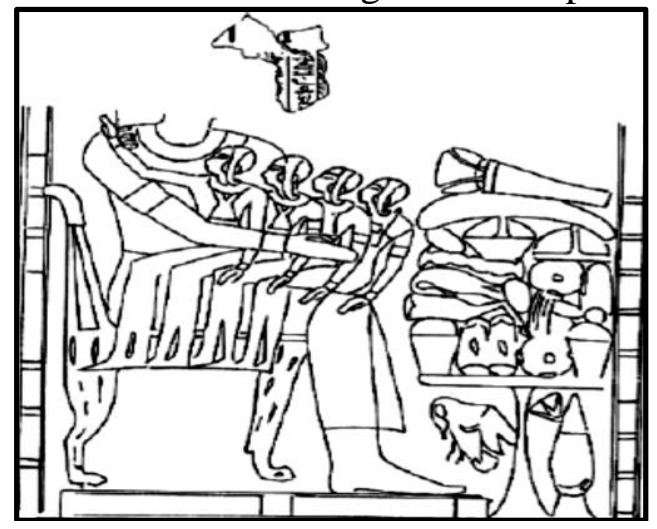

Fig. 6: Four princes sitting on the lap of a tutor in TT 226

(After Labib Habachi, Tomb No 226 of the Theban Necropolis and its Unknown Owner, 64, Fig. 3)

${ }^{32}$ Megaera C. Lorenz, the Role of Male Royal Offspring in 18th Dynasty Egypt, A Dissertation Submitted to the Faculty of the Division of the Humanities in Candidacy for the Degree of Doctor of Philosophy, the University of Chicago, (Chicago, Illinois, 2017), 328, Fig. 76; Labib Habachi, "Tomb No 226 of the Theban Necropolis and its Unknown Owner", in W. Helck (Ed.), Festschrift für Siegfried Schott zu seinem 70. Geburtstag, (Wiesbaden 1968), 64, Fig. 3; Dominic Montserrat, Akhenaten: History, Fantasy and Ancient Egypt, 35, Fig. 2. 6.

33 Catharine Hershey Roehrig, the Eighteenth Dynasty titles, 252, 294; Percy E. Newberry, The Sons of Tuthmosis IV, in The Journal of Egyptian Archaeology, Vol. 14, No. 1/2 (1928), 83, 85. 
An $18^{\text {th }}$ Dynasty stela from the tomb of Meryre at Saqqara that is recently preserved in Kunsthistotisches Museum at Vienna (inv. no. AS 5814), ${ }^{34}$ shows Meryre with prince Siatum, most probably one of the sons of king Amenhotep III, sitting sideways in front-facing position on his lap. The tutor Meryre is mentioned in the inscription above him to be "the Overseer of Nursing of the Good God imy-r3 $m n^{c} t n$ nfr ntr", and "the Treasurer imy$r 3 s \underline{d} 3 t t^{\prime 35}$ His left hand gently touches the back of the prince's head, while with his right hand he holds a type of fruit to the mouth of the prince (Fig. 7).

Prince Siatum, who is titled in the above inscription as "the son of the king whom his father loves", is seen with an incense cone on the head and a long wide side lock of hair. ${ }^{36} \mathrm{He}$ is dressed in a pleated kilt provided with a long sash. His left hand is hanging down before the knee of Meryre, while the right one rests on the hip of Meryre and holds a lotus blossom. ${ }^{37}$ It is worth mentioning that the motif represented here for a prince sitting on the lap of his tutor was included in the context of a family banquet scene.

\footnotetext{
${ }^{34}$ David Berg, "The Vienna Stela of Meryre", in The Journal of Egyptian Archaeology, Vol. 73 (1987), 213, Pl. 2.

${ }^{35}$ Betsy M. Bryan, The Reign of Thutmose IV, (Baltimore and London: The Johns Hopkins University Press, 1991), 66.

${ }^{36}$ The traditional side lock of hair became wider by the New Kingdom period for both girls and boys. The wide side lock was a fashion for the royal children and the high priest of Memphis that was usually a price. (Erika Feucht, Childhood, 262)

37 Catharine Hershey Roehrig, the Eighteenth Dynasty titles, 241, 242; The lotus is generally regarded as a highly regenerative and rejuvenating symbol with a broad semantic connotation. The holding and smelling of the lotus can be demonstrated early as an established element of the female depictions. Its association to the images of children recalling the concept of the young sun god that appears as a child on the lotus as a symbol of rebirth. The species of the lotus flower that is widely represented in the scenes, particularly in banquets and offerings, is the blue lotus (Nymphaea cerulean) that is represented in Gardiner's Sign-List (M9 seshen) with its characteristic feature of the head hanging to the side under its weight. Gabriele Pieke, "Der Grabherr und die LotosblumeZu lokalen und geschlechtsspezifischen Traditioneneines Motivkreises", in Miroslav Bárta, the Old Kingdom Art and Archaeology, Proceedings of the Conference held in Prague May 31-June 4, 2004, (Czech Institute of Egyptology, Faculty of Arts, Charles University in Prague, 2006), 260, 274; Richard H. Wilkinson, Reading Egyptian Art, 121.
} 


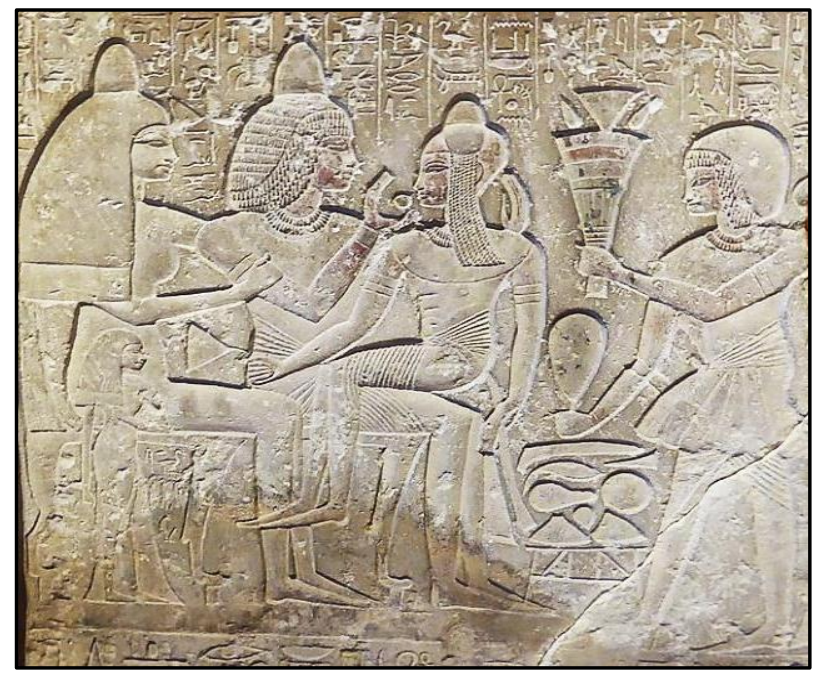

\section{Fig. 7: Meryre with prince Siatum on his lap}

(After David Berg, The Vienna Stela of Meryre, Pl. 2)

A scene on the northern wall of the vestibule of the tomb of Hekarnehhe TT 64 at Thebes in Sheikh Abd el-Qurna cemetery depicts the young prince Thutmose IV sitting sideways in front-facing position on the lap of his tutor and guardian Hekareshu, ${ }^{38}$ who appears as an elderly man with slight folds of fat on the chest. He is seated on a high back chair and places his left hand at the rear of the prince, while the right one is reposed on the hip of the prince (Fig. 8). ${ }^{39}$

Thutmose IV appears as a child king (a miniature king) in order to reflect his earlier relationship to his tutor Hekareshu. He is shown with his all royal insignia; a uraeus on the forehead, a hek scepter in the right hand, Ankh sign in the left hand, a pectoral inscribed with the prenomen of

\footnotetext{
${ }^{38}$ Hekareshu was the father of the tomb's owner Hekarnehhe. He was known to be "the tutor of the son of the king Amenhotep II", and "the tutor of the children of the king". Hekareshu and his son were both responsible for running the school at the temple of Mut. They most probably came from Nubia. Hekarshu most probably died just after or before the death of king Thutmose IV. Catharine Hershey Roehrig, the Eighteenth Dynasty titles, 207; Betsy M. Bryan, The Reign of Thutmose IV, 54; Percy E. Newberry, The Sons of Tuthmosis IV, 83; Arielle P. Kozloff, Amenhotep III: Egypt's Radiant Pharaoh, (Cambridge University Press, 2012), 38, 39, Fig. 6.

${ }^{39}$ Anne K. Capel, Glenn Markoe, and Betsy M. Bryan, Mistress of the House Mistress of Heaven Women in Ancient Egypt, (New York: Hudson Hills press, 1996), 18, Fig. 10; Betsy M. Bryan, The Reign of Thutmose IV, Pl. II, Fig. 5a; Megaera C. Lorenz, the Role of Male Royal Offspring in 18th Dynasty Egypt, 417, Fig. 100; Cristina Pino Fernández, "Una Posible Damnatto Memoriae Dethutmose IV en Tebas", in BAEDE Boletín de la Asociación Española de Egiptología, núm. 24, (2015), 116, Fig. 5.
} 
Tuthmosis IV and the feet rest on a stool ornamented with a representation of nine recumbent prisoners. ${ }^{40}$

The inscription above prince Thutmose IV is "the eldest son of the king from his body, his beloved one, whom Amun himself magnified to be the lord of what the Aten encircles, the lord of the Two Lands, Menkheprure", while the inscription above the tutor Hekreshu gives his name and titles: "God's father it ntrr, who nurtured the god šdi ntr, Beloved of the Sovereign, Tutor of the eldest son of the king from his body $m n^{c} y n$ s3 nswt smsw $n \underline{h t} . f$, Thutmose kha khau (the appearance of the crowns)". ${ }^{41}$

It is worth mentioning that the child king here is just looking at the face of his guardian without making any hand gestures towards him in contrast to the usual interacts towards the female nurse.

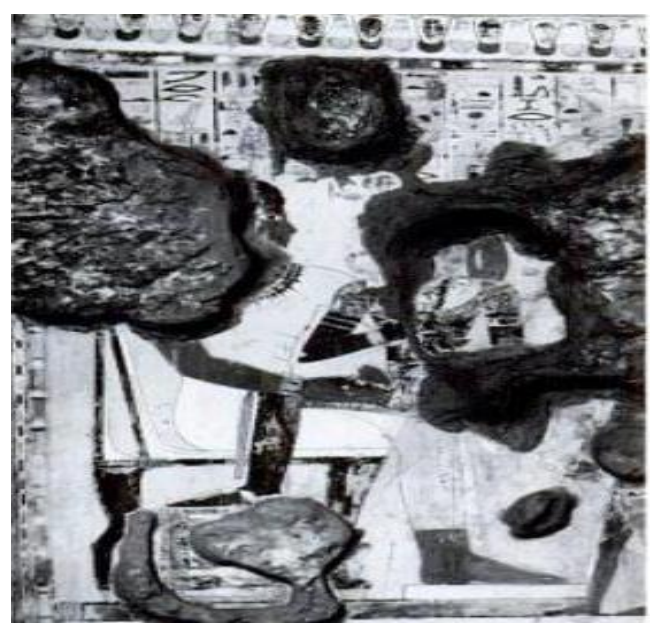

Fig. 8: The child king Thutmose IV sitting on the lap of his guardian Hekareshu

(After Anne K. Capel, Glenn Markoe, and Betsy M. Bryan, Mistress of the House Mistress of Heaven, 18, Fig. 10)

Such motif of a king in a miniature image as a child sitting on a lap of his life size guardian is considered to be the only case for a non-royal

\footnotetext{
${ }^{40}$ Percy E. Newberry, The Sons of Tuthmosis IV, 83.

${ }^{41}$ This is the only inscription that titled Thutmose as "the eldest son of the king s3 nsw $s m s w "$. This title together with the title God's father were held after Thutmose IV became a king. Brian Alm, Thutmose IV, in NILE Magazine, No.12, (2018), 43; Betsy M. Bryan, The Reign of Thutmose IV, 41; David O'Connor and Eric H. Cline, Amenhotep III Perspectives on His Reign, (United States of America: University of Michigan Press, 2001), 41; Catharine Hershey Roehrig, the Eighteenth Dynasty titles, 205.
} 
individual that appears in a larger scale than the king. ${ }^{42}$ This indicates that the relationship between the king and his tutor and guardian is a distinct one that will last throughout their lives.In the tomb of Horemhab TT 78 at Thebes in Sheikh Abd el-Qurna cemetery there is a representation in the middle register of a banquet scene at the north end of the eastern wall of the transverse hall for Horemheb, who was a high dignitary noble and a royal scribe $s \check{s} n s w$ held the title of "Scribe of Elite Troops $s \check{s} n s w m 3^{c}$ mry. $f$ ", with princess Amenemopet, the daughter of king Thuthmose IV, sitting on his lap (Fig. 9). ${ }^{43}$

The two individuals are seen facing each other. Horemheb is seated on a folding stool that was popularly used by the military individuals. He wears a white cone of an aromatic scent on his small wig and a wide collar around the neck. He is dressed in a long transparent garment that reaches to the ankles. The inscription surrounding the image of Horemheb did not mention the title "Royal Tutor" that is supposed to affirm his relation to the princess as her tutor, but only the title "Royal Scribe. ${ }^{44}$

As for the princess she is represented nude as was the tradition for being a child. She just wears a crown and a pair of white sandals. She grasps with her right hand a lotus blossom to the nostrils of her tutor Horemheb, while touching his right shoulder with her left hand. ${ }^{45}$

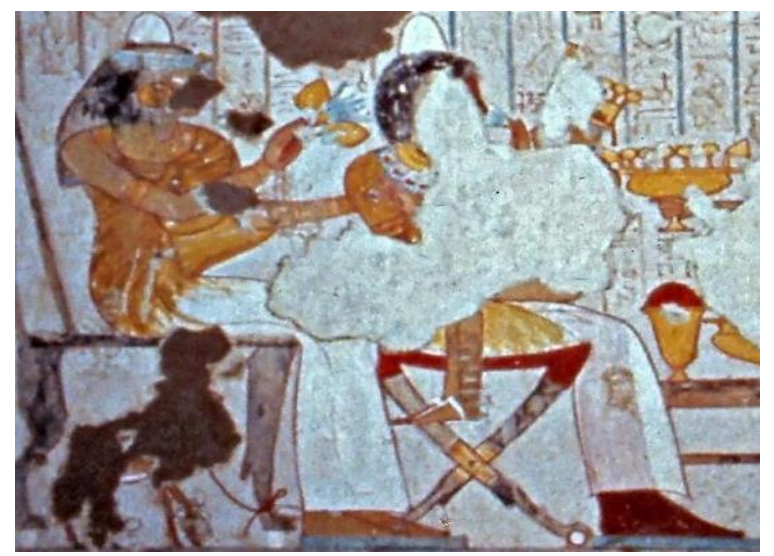

Fig. 9: the royal scribe Horemheb with princess Amenemopet on his lap (After Annelies and Artur Brack, Das Grab des Haremheb, Pl. 36)

\footnotetext{
${ }^{42}$ Anne K. Capel, Glenn Markoe, and Betsy M. Bryan, Mistress of the House Mistress of Heaven, 19.

${ }^{43}$ Aidan Dodson and Jac. J. Janssen, "A Theban Tomb and Its Tenants", in JEA 75, (1989), 137; Arielle P. Kozloff, Amenhotep III: Egypt's Radiant Pharaoh, 156; Betsy M. Bryan, The Reign of Thutmose IV, 282.

${ }^{44}$ Catharine Hershey Roehrig, the Eighteenth Dynasty titles, 236, 237, Pl. 19.

45 Annelies and Artur Brack, "Das Grab des Haremheb, Theben Nr. 78", in Archäologische Veröffentlichungen 35, (Mainz am Rhein: Verlag Philipp von Zabern, 1980), Pls. 36, 85.
} 


\section{SitTing On Tutor's LAP IN STATUARY}

The depiction of a child on a man's lap was so popular in the New Kingdom iconography. It denotes that the adult is either the child's parent or his educator or tutor. Concerning the man, who held the office of tutor of royal children, it was customary to commemorate his position by representing himself together with his charges seated on his lap. ${ }^{46}$

Senmen was the brother of the famous $18^{\text {th }}$ Dynasty architect Senenmut and like his brother he was a tutor of princess Neferure, the daughter of Queen Hatshepsut. He most probably preceded his brother in the office, and died in the early years of the reign of Queen Hatshepsut, then Senenmut was promoted to be the chief tutor of the princess. Senmen is represented in a statue seated with the child princess on his lap. This statue was found together with a small standing statue for Senmen's wife Tu-ef engraved in high relief on the peak of one of the ledges of the hill of the cemetery of Sheikh Abd el-Qurna. The inscription carved on the statue mentions the title of Senmen: "the Steward and Tutor of the god's wife imy-r3 pr $m n^{c} n$ hmt ntr" (Fig. 10). ${ }^{47}$

Senmen is shown seated with a crossed right leg and a raised left knee that serves as a backrest for the child princess Neferure, whose name is inscribed on her lap and appears with the traditional side lock of hair. His right hand rests on his knee beside the princess, while holding her ankles with the left hand. The inscription on the lap of Senmen gives a prayer "May Osiris the Great God, the Lord of Eternity (give) pert er kheru offerings to the ka of the Prince and Steward Senmen", while on the base of the statue was written another prayer; "May he (god Osiris) give a reception of loaves on his altars as daily offerings for the ka of the Steward and Tutor of the god's wife (Neferura), he who is approved by his urban god, Senmen, the True of Voice" ${ }^{48}$

\footnotetext{
${ }^{46}$ Boyo Ockinga and Susanne Binder, Fragments of an Amarna-age Stele in the Teti Pyramid Cemetery North, 510.

${ }^{47}$ Norman de Garis Davies, "The tomb of Senmen, brother of Senmut", in Proceedings of the Society of Biblical Archoology 35, (1913), 282; Catharine Hershey Roehrig, the Eighteenth Dynasty titles, 59, 64.

${ }^{48}$ Norman de Garis Davies, The tomb of Senmen, brother of Senmut, 285.
} 


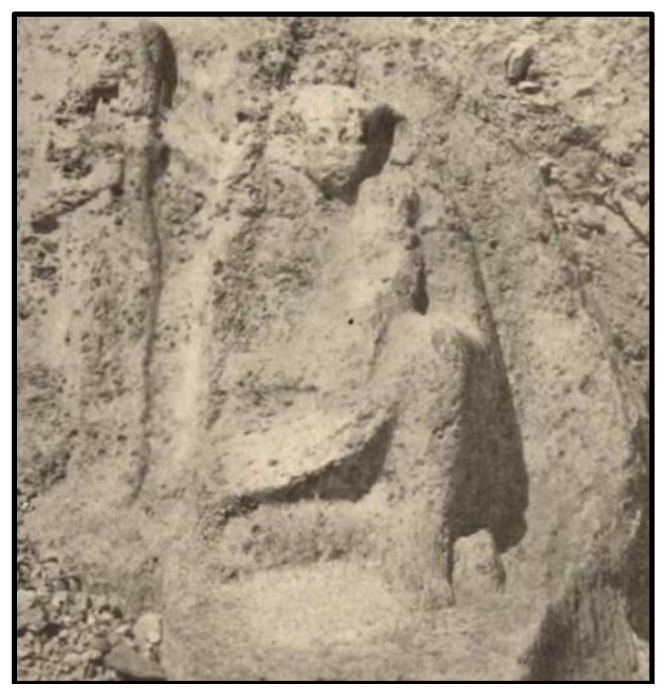

\section{Fig. 10: Statue of the tutor Senmen with princess Neferure on his lap}

(After Norman de Garis Davies, The tomb of Senmen, brother of Senmut, Pl. XLIX)

Senenmut was a royal tutor and guardian to the daughter of Queen Hatshepsut, princess Neferura. This position was commemorated in at least ten statues of the princess and her tutor, of which seven are block statues that only expose the heads. Two other unique statues that clearly represent the princess sitting in a direct manner on the lap of her tutor Senenmut (Fig. 11). ${ }^{49}$

The first statue that is considered to be the earliest statue for Senenmut and princess Neferure is recently preserved in the British Museum (BM 174) (Fig.11) ${ }^{50}$ It shows the princess in the same attitude of sitting on the lap of her tutor but at a different angle or orientation. She is facing forward and this time the chest of Senenmut that serves as her backrest. He embraces her with his both hands on her torso in a protective mode under his chin and completely envelopes her body in his mantle. The inscriptions on the statue mentions that Senenmut is the "Chief Overseer of Princess Neferure imy-r3 pr (wr)n s3t nswt". ${ }^{51}$

\footnotetext{
${ }^{49}$ Anne K. Capel, Glenn Markoe, and Betsy M. Bryan, Mistress of the House Mistress of Heaven, 18; Suzanne Ratié, "Attributs et destinée de la princesse Neferoure", in Bulletin de la Société d'Égyptologie, Genève 4, (1980), 1-6.

${ }^{50} \mathrm{H}$ R Hall, Hieroglyphic texts from Egyptian stelae, etc., in the British Museum, Part 5, (London, 1914), Pl. 32; E. R. Russmann, Eternal Egypt: Masterworks of Ancient Art from the British Museum, (London, 2001), 44; James K. Thomson, "A First Acolyte of Amun", in The Journal of Egyptian Archaeology 84, (1998), Pl. XXII, 1.

${ }^{51}$ Catharine Hershey Roehrig, the Eighteenth Dynasty titles, 71.
} 
The princess appears with two traditional signs of childhood; the side lock of hair and holding the index finger to the mouth. Such unique style of statue in expressing the protective and guarding role of the tutor towards the individual whom he charges seems to be the forerunner for the popular style of block statue housing two individuals that was first known in the mid of the $18^{\text {th }}$ Dynasty and first used by the tutor Senenmut. ${ }^{52}$

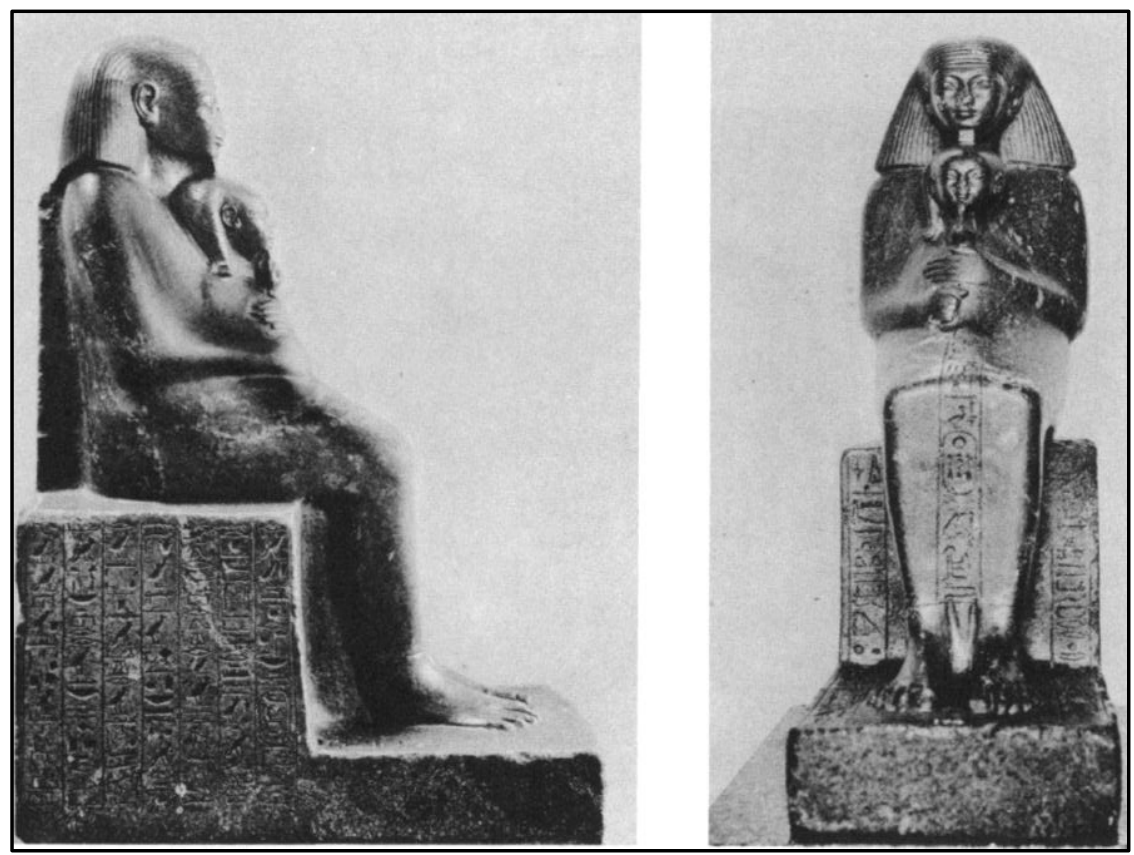

\section{Fig. 11: The statue of Senenmut with princess Neferura in the British Museum}

(After H. R. Hall, "The Statues of Sennemut and Menkheperresenb in the British Museum", in JEA 14, (1928), Pl. II)

The other statue for Senenmut that is similar to the statue of his brother Senmen is recently preserved in the Egyptian Museum at Cairo (CG 42116)(Fig. 12) ${ }^{53}$ It shows the young princess sitting sideways on the lap

\footnotetext{
${ }^{52}$ In addition to the seven block statues of Senenmut as a tutor there are only four examples of block statues for other tutors (Benermerut, Senneferi, Minmose, and Tjenuna) with the individuals whom they charges. They date back to the $18^{\text {th }}$ Dynasty, three belong to the reign of king Thuthmose III, and one to the reign of king Amenhotep III; Catharine Hershey Roehrig, the Eighteenth Dynasty titles, 278, 282, 283, 284.

${ }^{53}$ Georges Legrain, Statues et statuettes de rois et de particuliers, Catalogue général des antiquités égyptiennes du Musée du Caire, Vol. I, (Cairo: l'Institut français d'archéologie orientale, 1906), Pl. LXVII; Gerry D. Scott, The History and Development of the Ancient Egyptian Scribe Statue, (Yale University, 1989), Cat. No. 229; Cyril Aldred, New Kingdom Art in Ancient Egypt during the Eighteenth Dynasty 1570 to 1320 B.C.,
} 
of Senenmut, who is seated on the ground with a crossed right leg and a raised left knee that serves as a backrest for the princess. ${ }^{54} \mathrm{He}$ embraces her with his left hand close to his chest and beneath his chin, while his right hand rests on the princess's lap. The princess is represented with a uraeus on the forehead, a side lock of hair and holding the right index finger to her mouth. ${ }^{55}$ The inscription on the statue gives the titles of Senenmut in relation to god Amun, princess Neferure, and Queen Hatshepsut: "Steward of Amun", "Overseer of Princess Neferure", and "Overseer of the Lady of the Two Lands". ${ }^{56}$
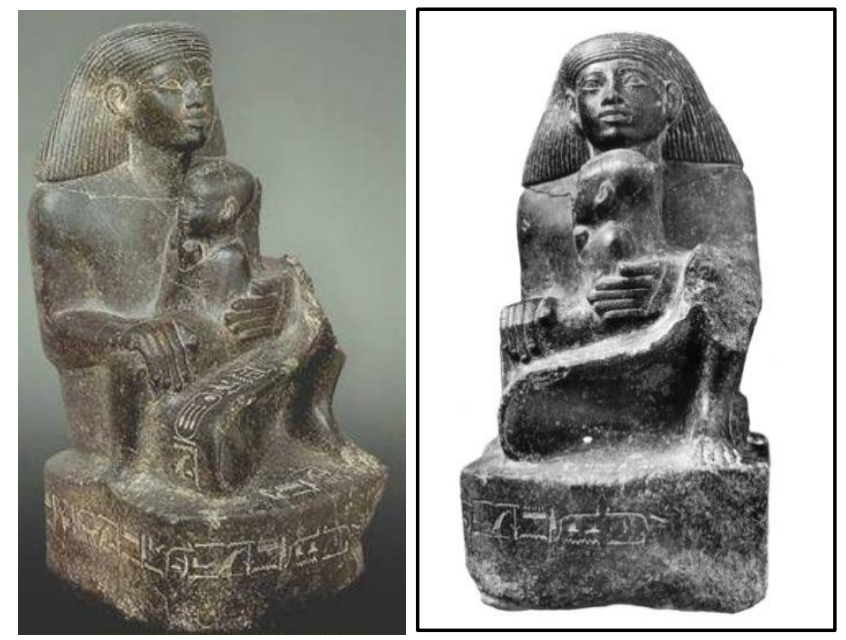

\section{Fig. 12: The statue of Senenmut with princess Neferura in the Egyptian Museum at Cairo}

(After Edith Bernhauer, Innovationen in der Privatplastik. Die 18. Dynastie und ihre Entwicklung, Philippika 27, (Wiesbaden 2010), 317, pl. 21; https://www.ifao.egnet.net/bases/cachette/docs/vues/cg_0062_42116.jpg)

Sobekhotep was a prominent official during the reign of king Thuthmose IV. His name means "Sobek is Satisfied", as he was a high priest of Sobek

(Londres, 1961), pl. 32; Kazimierz Michalowski, L'art de l'Égypte ancienne (Nouvelle édition revue et augmentée par Jean-Pierre Corteggiani et Alessandro Roccati), (Paris, 1994), 442, fig. 391.

${ }^{54}$ The attitude of raising one Knee as a backrest for the child is so familiar in the motif of the nursing mother; Alessandro Bongioanni and Maria Sole Croce, The Treasures of Ancient Egypt from the Egyptian Museum in Cairo, (Rizzoli, 2003), 146; C.H. Roehrig, "The Statue of the Royal Nurse Sitre with her Nursling Maatkare Hatshepsut", in M. Eldamaty, M. Trad (éd.), Egyptian Museum Collections around the World. Studies for the Centennial of the Egyptian Museum, II, (Cairo 2002), 1006, n. 17.

${ }^{55}$ H. Jacquet-Gordon, "Concerning a Statue of Senenmut", in BIFAO 71, (1972), 142, 150; Catharine H. Roehrig, Renée Dreyfus, Cathleen A. Keller, Hatshepsut from Queen to Pharaoh, (Metropolitan Museum of Art, 2005), 112-113, Fig. 49.

${ }^{56}$ Catharine Hershey Roehrig, the Eighteenth Dynasty titles, 72. 
the crocodile god. He was the tutor of the crown prince Amenhotep III, with whom he is represented in an unusual black granite statue at Brussels Musées royaux (E. 6856), but unfortunately the heads are completely damaged (Fig. 13). ${ }^{57}$

The statue shows Sobekhotep sitting in the traditional pose of the scribe with cross-legged and the child prince Amenhotep III facing forward on his lap. ${ }^{58} \mathrm{He}$ embraces the prince in a protective mode by covering his torso and crossed hands with his both hands. He is dressed in a short kilt that is towed tightly over his knees serving as a resting seat for the prince, who wears the royal short plain shendyt kilt and is represented barefoot. There is a protrusion to the right of the prince's head that seems to be remains of the side lock of hair.

The inscription carved on the kilt of Sobekhotp gives his titles except for the title "Royal Tutor": imy-r3 s $\underline{d} 3 t$ the Treasurer, $\underline{t} 3 y$ hww hr wnmy nswt the Fan Bearer on the Right Hand of the King, and it nt $\underline{t} r$ mry ntr the God's Father the Beloved of the God. As for the inscription on the sides of the prince's feet, it mentions that the prince Amenhotep Mery-khepesh is the son of the king from his body (s3 nswt $n \underline{h t} . f) .{ }^{60}$

The inscriptions on the statue also mentions that the statue is a gift that the king grants to that two main deities of El Fayum. It was most likely originally placed in the temple of god Sobek at Shedet, the ancient capital of El Fayum, where the tutor Sobekhotep was a mayor. ${ }^{61}$

The Statue of the tutor Sobekhotep with prince Amenhotep III is considered to be the earliest example in statuary for a miniature adult crown prince sitting on the lap of his tutor. ${ }^{62}$

\footnotetext{
57 B. van de Walle، "Precisions Nouvelles sur Sobek-hotep Fils de Min", in RdE 15 (1963), 77-85; J. Capart, "Une Statue de Sebekhotep, Precepteur Royal", in Bulletin des Musees Royaux d'Art et d'Histoire, No. 4, (1938), 83-86, Figs. 8, 9.

${ }^{58}$ The origin of the traditional sitting pose for the scribe with cross-legged dates to the Old Kingdom period. The pose was preserved in the following periods, but with a new developed style by the Middle Kingdom period, where the cross-legged were completely covered by the man's clothing and all lap area was inscribed with texts. During the New Kingdom the legs were usually left uncover. (James K. Thomson, A First Acolyte of Amun, , 215)

${ }^{59}$ Catharine Hershey Roehrig, the Eighteenth Dynasty titles, 217, 218; Betsy M. Bryan, The Reign of Thutmose IV, 70.

${ }^{60}$ Catharine Hershey Roehrig, the Eighteenth Dynasty titles, 219.

${ }^{61}$ Arielle P. Kozloff, Amenhotep III: Egypt's Radiant Pharaoh, 34.

${ }^{62}$ Catharine Hershey Roehrig, the Eighteenth Dynasty titles, 287.
} 


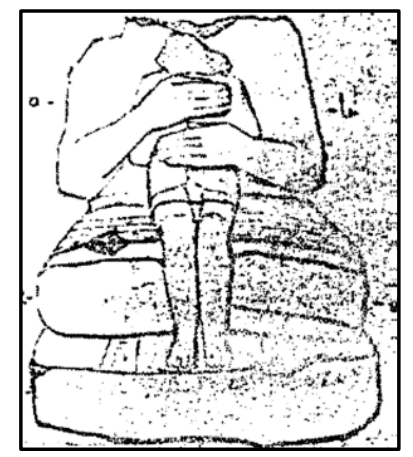

Fig. 13: Statue of the tutor Sobekhotep with prince Amenhotep III on his lap

(After Catharine Hershey Roehrig, the Eighteenth Dynasty titles, Pl. 15)

\section{SITTING ON HUSBAND'S LAP IN SCENES}

The motif of a woman sitting on the lap of her husband is primarily restricted to the reign of king Akhenaten and not attested before. The motif is found on a limestone panel from the city of Tel El Amarna that is partly destroyed and is recently preserved in the Louvre Museum (E 11624) (Fig. 14). ${ }^{63}$ It shows king Akhenaten seated on his throne, which is decorated with the traditional symbol of the unification of the two lands of ancient Egypt between its leonine legs, with his wife queen Nefertiti sitting sideway on his lap and most probably two of their little princesses on the queen's lap. In spite of the badly damaged upper half of the panel with the inscription, cartouches, upper part of the enthroned king, the head of the queen, and figures of princesses except for their feet, the identification of the royal couple is well attested and recognized from the characteristic Amarna style of art and the other illustrations for the members of the royal family together. ${ }^{64}$

\footnotetext{
${ }^{63}$ Norman de Garis Davies, "The Graphic Work of the Expedition", in the Metropolitan Museum of Art Bulletin 18, (1923), Fig. 4; Matthew F. Petrie, Tell el Amarna (London:Methuen, 1894), 40-41, pl. 1 n.16.

${ }^{64}$ Arlette David, "A Throne for Two: Image of the Divine Couple during Akhenaten's Reign", in Journal of Ancient Egyptian Interconnections, http://jaei.library.arizona.edu, Vol. 14 (June 2017), 1, 2, Fig. 1.
} 


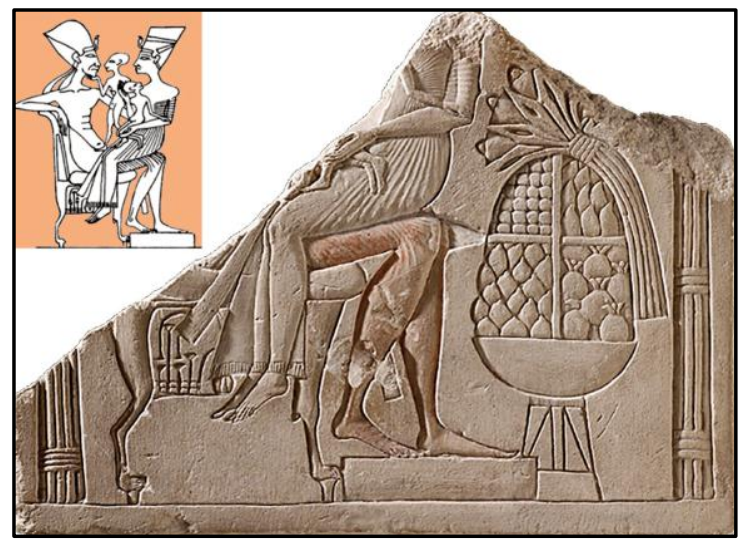

Fig. 14: A Relief for king Akhenaten with Nefertiti on his lap

(After Arlette David, A Throne for Two, 1, Fig. 1)

It is suggested that such unique Amarna motif of a queen sitting on the lap of her husband recalling the traditional sacred relation between the royal daughter or wife with the god, particularly god Amun, that was attested from the Old Kingdom period. It symbolizes the role played by the king as a divine father and spouse of queen Nefertiti, as is indicated in the later example in royal statuary for a $25^{\text {th }}$ Dynasty couple statuette of god Amun and his divine daughter and wife princess Amenirdis I. ${ }^{65}$ In addition the motif of lap sitting reflects the sexual intimacy between the royal couple.

\section{SitTING ON HUSBAND's LAP IN STATUARY}

There are two unique examples for the motif of sitting on a husband's lap in the royal statuary; one dates back to the Amarna Period for king Akhenaten, while the other dates to the Third Intermediate Period for god Amun.

The statuette of king Akhenaten is made of limestone and was discovered in a house of a sculptor at the city of Tel El Amarna. It is recently preserved in the Egyptian Museum at Cairo (JE 44866) (Fig. 15). ${ }^{66}$ The statue is unfinished giving no textual references to the king or the female princess sitting on his lap, but the king is identified from the blue crown (Khepresh crown) on the head and the distinguished and unique Amarna style of art that appears clearly in the statuette. As for the female figure

\footnotetext{
${ }^{65}$ Arlette David, A Throne for Two, 2, 3 .

${ }^{66}$ H. Frankfort, Heresy in a Theocratic State, in Journal of the Warburg and Courtauld Institutes, Vol. 21 No.3/4, (1958), 159; Rebecca Clifton, Art and Identity in the Age of Akhenaten, $\mathrm{PhD}$ Thesis, the School of Historical and Philosophical Sciences at the University of Melbourne, (2019), 412, Fig. 2.117.
} 
there was a controversy over her identity, whether she was his beloved wife queen Nefertiti, his secondary wife Kiya, or his eldest daughter Meritaten, ${ }^{67}$ but any way the attitudes and interaction between the king and the female figure denote that she is his wife. The king appears kissing her in her mouth. He holds her neck with his right hand, while placing the left on her back. She in turn holds his right elbow with her left hand, while embracing him with her left arm. ${ }^{68}$

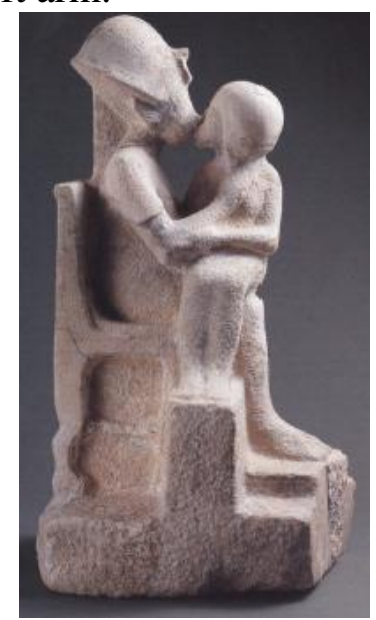

Fig. 15: The Unfinished Statuette of king Akhenaten kissing a female figure

(After Dorothea Arnold, The Royal Women of Amarna, 103, Fig. 96)

There is a unique example for the motif of sitting on a god's lap in the royal statuary. It is a small couple statuette that dates back to the $25^{\text {th }}$ Dynasty and is displayed in the Egyptian museum at Cairo (CG 42199) (Fig. 16). ${ }^{69}$ The statuette was discovered to the north of Karnak. It is made of blue faience and is badly damaged. It shows the couple, whose heads and necks are completely destroyed, in the attitude of one sitting on the lap of the other. According to the inscriptions engraved on the sides and back of the throne the couple is god Amun and princess Amenirdis I, who was the daughter of the Kushite King Kashta and Queen Pebatjma: ${ }^{70}$

\footnotetext{
${ }^{67}$ John Ashton and David Down, Unwrapping the Pharaohs, (China, 2006), 150.

${ }^{68}$ Dorothea Arnold, The Royal Women of Amarna: Images of Beauty from Ancient Egypt (New York: Metropolitan Museum of Art, 1996), 103, Fig. 96; W. elSaddik, Die Konigsfamilie in der Kunst der Amarnazeit. In C. Tietze \& E. Hornung (Eds.), Amarna. Lebensräume - Lebensbilder - Weltbilter, Austellungskatalog Echnaton und Amarna, Ägypten im neuen Licht, 6. September 2010 bis 30. Januar 2011im GustavLübcke Museum der Stadt Hamm, (Weimar: Arcus-Verlag, 2010), Abb. 10.

${ }^{69}$ Georges Legrain, "Sur un groupe d'Amon et d'Améniritis I", in Recueil deTravaux 31 (1909), 139-142.

${ }^{70}$ Manal B. Hammad, The Statuette Group of God Amun and Amenirdis I Cairo Museum (CG 42199), in Journal of Association of Arab Universities for Tourism and Hospitality
} 


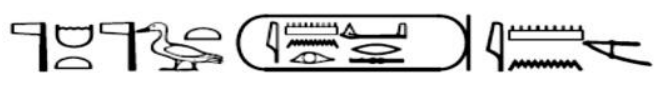

hmt nț s3t nț ( Tmn-ir-di-s(t) ) mry Tmn

God's wife, God's daughter, Amenirdis, beloved of Amun.

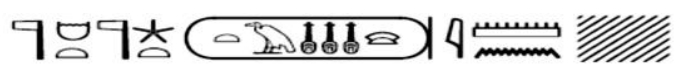

hmt ntr dw3t ntr ( hri - nfrw- mwt) [mry] Tmn

God's wife, Divine Adorer, Khaneferumut, beloved of Amun. 71

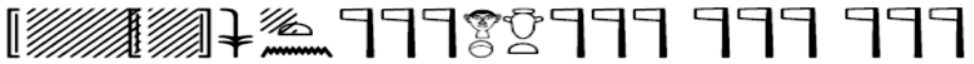

[ $\left.7 m n R^{\top}\right]$ nswt nțrw hr ib psḍt nțrw

[Amun Ra] king of the gods, who is in the middle of the Ennead of Gods.
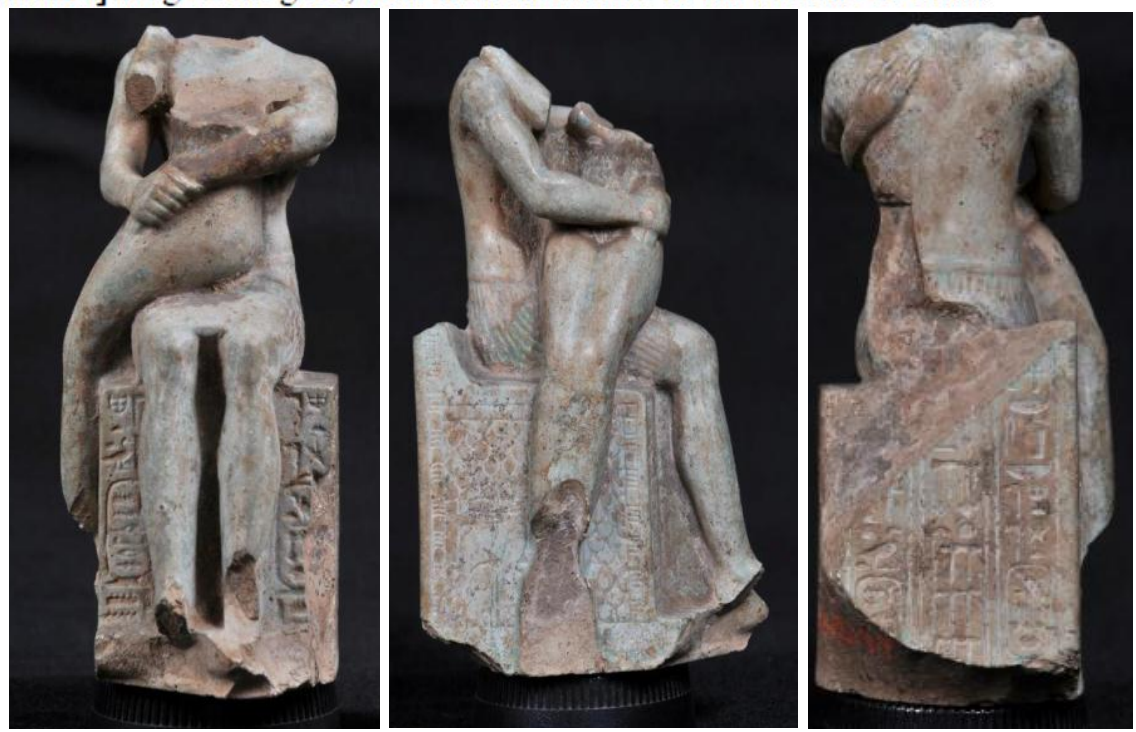

Fig. 16: The Couple Statuette of God Amun and Amenirdis I

(After Manal B. Hammad, The Statuette Group of God Amun and Amenirdis I Cairo Museum (CG 42199), 26, 27, 28, Figs. 1, 2, 4)

The statuette represents god Amun sitting on a low back throne, whose sides are decorated with geometrical motifs and a representation of the

(JAAUTH), Vol. 17 No. 1, (2019), 29, 30; see also William Kelly Simpson, "Egyptian Sculpture and Two-Dimensional Representation as Propaganda", in The Journal of Egyptian Archaeology, Volume 68 issue 1, (1982), 266-271.

${ }^{71}$ The name Khaneferumut is the name chosen by princess Amenirdis I after holding the office of the divine adorer and consort of god Amun. It means "She who appears in the perfection of Mut". The names of the princess were written inside cartouches as she enjoyed all the royal rights, particularly after ruling Egypt together with Shepenupet I that lasted for about 13 years. For Amenirdis and the title God' Wife see Betsy Bryan, "Property and the God's Wives of Amun", in Women and property in ancient Near Eastern and Mediterranean societies, conference organizers and editors Deborah Lyons and Raymond Westbrook, (Cambridge: Harvard Center for Hellenic Studies, 2003), 7. 
traditional symbol of the unification of the two lands of ancient Egypt " $s m 3 t 3 w y "$. He wears a short pleated kilt and a wide collar around the neck. He embraces the female figure of Amenirdis I sitting sideways on his lap with his both hands that appear clenched together on her waist. ${ }^{72}$

Amenirdis I, who was the Divine adorer (Adoratix), God's hand, and consort of god Amun and whose name means "Amun is the one who made her", ${ }^{73}$ appears in the statuette in a slightly smaller scale than the human figure of god Amun. She is dressed in a tight transparent sheath dress. In expressing the affection and intimacy towards the god that appears in the hand gestures of Amenirdis I, who tightly embraces the god passing her right hand beneath his armpit to rest on the back of his left shoulder, while the preserved little part of her left hand is placed on his right shoulder. ${ }^{74}$

\section{CONCLUSION}

In ancient Egypt the motif of lap sitting was not exclusive for the domain of women, but a number of examples were found in scenes and statuary for men represented themselves holding another individual on their laps, as indicated in Table 1:

\footnotetext{
${ }^{72}$ Manal B. Hammad, The Statuette Group of God Amun and Amenirdis I Cairo Museum (CG 42199), 28.

${ }^{73}$ The title God's Hand was more associated with Amenirdis I than any other God's Wife of her period. The title Adoratix was frequently used by Amenirdis in association to the title of God's Wife. Aidan Dodson, "The Problem of Amenirdis II and the Heirs to the Office of God's Wife of Amun during the Twenty-Sixth Dynasty", in JEA 88, (2002), 180-181,186.

${ }^{74}$ Catalogue général des antiquités égyptiennes du musée du Caire Nos 42192- 42250, Statues et statuettes de rois et de particuliers III, (Cairo: IFAO, 1914), 8-9, Pl. 7.
} 
Table 1: The collected examples for the motif of sitting on a man's lap in scenes and statuary

\begin{tabular}{|c|c|c|c|c|c|c|c|}
\hline No. & Scene/ Statue & Date & Location & $\begin{array}{c}\text { The seated } \\
\text { man's } \\
\text { Identity }\end{array}$ & $\begin{array}{c}\text { The seated man's } \\
\text { title }\end{array}$ & $\begin{array}{c}\text { The individual on } \\
\text { the lap }\end{array}$ & $\begin{array}{l}\text { The attitude } \\
\text { of lap sitting }\end{array}$ \\
\hline 1 & $\begin{array}{l}\text { Scene of } \\
\text { Dedusobek and } \\
\text { his daughter }\end{array}$ & $\begin{array}{l}\text { Middle } \\
\text { Kingdom, } 12^{\text {th }} \\
\text { Dynasty }\end{array}$ & $\begin{array}{l}\text { The Egyptian } \\
\text { Museum (Cairo, } \\
\text { CG 20596). }\end{array}$ & Father & $\begin{array}{l}\text { A draftsman and a } \\
\text { chief of scribes. }\end{array}$ & A child/ girl & $\begin{array}{l}\text { Facing } \\
\text { forward }\end{array}$ \\
\hline 2 & $\begin{array}{l}\text { Scene of Thener } \\
\text { with his daughter }\end{array}$ & $\begin{array}{l}\text { New Kingdom, } \\
18^{\text {th }} \text { Dynasty }\end{array}$ & $\begin{array}{l}\text { The Egyptian } \\
\text { Museum at Cairo } \\
\text { (JE 18924). }\end{array}$ & Father & $\begin{array}{l}\text { An outline } \\
\text { draftsman. }\end{array}$ & A child/girl & Sideways \\
\hline 3 & $\begin{array}{l}\text { The royal statue } \\
\text { of Siptah }\end{array}$ & $\begin{array}{l}\text { New Kingdom, } \\
19^{\text {th }} \text { Dynasty }\end{array}$ & $\begin{array}{l}\text { Munich } \\
\text { Glyptothek no. } \\
122 .\end{array}$ & Father & $\begin{array}{l}\text { No preserved } \\
\text { inscriptions. }\end{array}$ & $\begin{array}{l}\text { A royal child/ a } \\
\text { miniature king }\end{array}$ & Sideways \\
\hline 4 & $\begin{array}{l}\text { Scene of Pahery } \\
\text { with prince } \\
\text { Wadjmose }\end{array}$ & $\begin{array}{l}\text { New Kingdom, } \\
18^{\text {th }} \text { Dynasty }\end{array}$ & $\begin{array}{l}\text { West wall of the } \\
\text { tomb of Pahery } \\
\text { No. } 3 \text { at El Kab. }\end{array}$ & Tutor & $\begin{array}{l}\text { The tutor of prince } \\
\text { Wadjmose, the ha- } \\
\text { prince Paheri. }\end{array}$ & $\begin{array}{l}\text { A royal child/ } \\
\text { prince }\end{array}$ & Sideways \\
\hline 5 & $\begin{array}{l}\text { Scene of Min } \\
\text { with prince } \\
\text { Amenhotep II }\end{array}$ & $\begin{array}{l}\text { New Kingdom, } \\
18^{\text {th }} \text { Dynasty }\end{array}$ & $\begin{array}{l}\text { South wall of the } \\
\text { transverse hall, } \\
\text { tomb of Min TT } \\
109 .\end{array}$ & Tutor & $\begin{array}{l}\text { The Father Tutor of } \\
\text { Prince Amenhotep. }\end{array}$ & $\begin{array}{l}\text { A royal child/ } \\
\text { prince }\end{array}$ & Sideways \\
\hline
\end{tabular}




\begin{tabular}{|c|c|c|c|c|c|c|c|}
\hline 6 & $\begin{array}{l}\text { Scene of an } \\
\text { unknown } \\
\text { individual with } \\
\text { four princes }\end{array}$ & $\begin{array}{l}\text { New Kingdom, } \\
18^{\text {th }} \text { Dynasty }\end{array}$ & $\begin{array}{l}\text { TT } 226 \text { at Sheikh } \\
\text { Abd el-Qurna }\end{array}$ & Tutor & $\begin{array}{l}\text { Royal Scribe, } \\
\text { Overseer of the } \\
\text { King's Tutors, and } \\
\text { Steward. }\end{array}$ & $\begin{array}{l}\text { Four royal } \\
\text { children/ princes }\end{array}$ & Sideways \\
\hline 7 & $\begin{array}{l}\text { Scene of Meryre } \\
\text { with prince } \\
\text { Siatum }\end{array}$ & $\begin{array}{l}\text { New Kingdom, } \\
18^{\text {th }} \text { Dynasty }\end{array}$ & $\begin{array}{l}\text { Kunsthistotisches } \\
\text { Museum at } \\
\text { Vienna (inv. no. } \\
\text { AS 5814). }\end{array}$ & Tutor & $\begin{array}{l}\text { the Overseer of } \\
\text { Nursing of the Good } \\
\text { God, and the } \\
\text { Treasurer. }\end{array}$ & $\begin{array}{l}\text { A royal child/ } \\
\text { miniature adult } \\
\text { prince }\end{array}$ & Sideways \\
\hline 8 & $\begin{array}{l}\text { Scene of } \\
\text { Hekareshu with } \\
\text { prince Thutmose } \\
\text { IV }\end{array}$ & $\begin{array}{l}\text { New Kingdom, } \\
18^{\text {th }} \text { Dynasty }\end{array}$ & $\begin{array}{l}\text { North wall of the } \\
\text { vestibule of the } \\
\text { tomb of } \\
\text { Hekarnehhe TT } \\
64 .\end{array}$ & $\begin{array}{l}\text { Tutor and } \\
\text { guardian }\end{array}$ & $\begin{array}{l}\text { God's father, who } \\
\text { nurtured the god, } \\
\text { Beloved of the } \\
\text { Sovereign, Tutor of } \\
\text { the eldest son of the } \\
\text { king from his body. }\end{array}$ & $\begin{array}{l}\text { A royal child/ a } \\
\text { miniature king }\end{array}$ & Sideways \\
\hline 9 & $\begin{array}{l}\text { Scene of } \\
\text { Horemhab with } \\
\text { princess } \\
\text { Amenemopet }\end{array}$ & $\begin{array}{l}\text { New Kingdom, } \\
18^{\text {th }} \text { Dynasty }\end{array}$ & $\begin{array}{l}\text { East wall of the } \\
\text { transverse hall of } \\
\text { the tomb of } \\
\text { Horemhab TT } \\
78 \text {. }\end{array}$ & Tutor & Royal Scribe & $\begin{array}{l}\text { A royal child/ } \\
\text { princess }\end{array}$ & Sideways \\
\hline 10 & $\begin{array}{l}\text { Private Statue of } \\
\text { Senmen with } \\
\text { princess Neferure }\end{array}$ & $\begin{array}{l}\text { New Kingdom, } \\
18^{\text {th }} \text { Dynasty }\end{array}$ & $\begin{array}{l}\text { On the peak of } \\
\text { one of the ledges } \\
\text { of the hill of } \\
\text { Sheikh Abd el- } \\
\text { Qurna cemetery. }\end{array}$ & Tutor & $\begin{array}{l}\text { The Steward and } \\
\text { Tutor of the god's } \\
\text { wife. }\end{array}$ & $\begin{array}{l}\text { A royal child/ } \\
\text { princess }\end{array}$ & Sideways \\
\hline 11 & $\begin{array}{l}\text { Private statue of } \\
\text { Senenmut with } \\
\text { princess Neferura }\end{array}$ & $\begin{array}{l}\text { New Kingdom, } \\
\text { 18th Dynasty }\end{array}$ & $\begin{array}{l}\text { The British } \\
\text { Museum (BM } \\
\text { 174). }\end{array}$ & Tutor & $\begin{array}{l}\text { Chief Overseer of } \\
\text { Princess Neferure. }\end{array}$ & $\begin{array}{l}\text { A royal child/ } \\
\text { princess }\end{array}$ & $\begin{array}{l}\text { Facing } \\
\text { forward }\end{array}$ \\
\hline 12 & $\begin{array}{l}\text { Private statue of } \\
\text { Senenmut with }\end{array}$ & $\begin{array}{l}\text { New Kingdom, } \\
18^{\text {th }} \text { Dynasty }\end{array}$ & $\begin{array}{l}\text { The Egyptian } \\
\text { Museum at Cairo }\end{array}$ & Tutor & $\begin{array}{l}\text { Steward of Amun, } \\
\text { Overseer of Princess }\end{array}$ & $\begin{array}{l}\text { A royal child/ } \\
\text { princess }\end{array}$ & Sideways \\
\hline
\end{tabular}




\begin{tabular}{|c|c|c|c|c|c|c|c|}
\hline & princess Neferura & & (CG 42116). & & $\begin{array}{l}\text { Neferure, and } \\
\text { Overseer of the } \\
\text { Lady of the Two } \\
\text { Lands. }\end{array}$ & & \\
\hline 13 & $\begin{array}{l}\text { Private Statue of } \\
\text { Sobekhotep with } \\
\text { Amenhotep III }\end{array}$ & $\begin{array}{l}\text { New Kingdom, } \\
18^{\text {th }} \text { Dynasty }\end{array}$ & $\begin{array}{l}\text { Brussels Musées } \\
\text { royaux } \\
\text { (E. 6856). }\end{array}$ & Tutor & $\begin{array}{l}\text { The Treasurer, the } \\
\text { Fan Bearer on the } \\
\text { Right Hand of the } \\
\text { King, and God's } \\
\text { Father the Beloved } \\
\text { of the God. }\end{array}$ & $\begin{array}{l}\text { A royal child/ a } \\
\text { miniature adult } \\
\text { crown prince }\end{array}$ & $\begin{array}{l}\text { Facing } \\
\text { forward }\end{array}$ \\
\hline 14 & $\begin{array}{l}\text { Scene of king } \\
\text { Akhenaten with } \\
\text { Nefertiti }\end{array}$ & $\begin{array}{l}\text { New Kingdom, } \\
\text { Amarna } \\
\text { Period, } 18^{\text {th }} \\
\text { Dynasty }\end{array}$ & $\begin{array}{l}\text { The Louvre } \\
\text { Museum (E } \\
11624) .\end{array}$ & $\begin{array}{l}\text { King/ } \\
\text { husband }\end{array}$ & $\begin{array}{l}\text { No preserved } \\
\text { inscriptions. }\end{array}$ & Wife & Sideways \\
\hline 15 & $\begin{array}{l}\text { Royal Statuette } \\
\text { of Akhenaten } \\
\text { with a female } \\
\text { figure }\end{array}$ & $\begin{array}{l}\text { New Kingdom, } \\
\text { Amarna Period, } \\
18^{\text {th }} \text { Dynasty }\end{array}$ & $\begin{array}{l}\text { The Egyptian } \\
\text { Museum at Cairo } \\
\text { (JE 44866) }\end{array}$ & $\begin{array}{l}\text { King/ } \\
\text { husband }\end{array}$ & $\begin{array}{l}\text { No accompanied } \\
\text { inscriptions. }\end{array}$ & Wife & Sideways \\
\hline 16 & $\begin{array}{l}\text { Royal statuette of } \\
\text { God Amun and } \\
\text { Amenirdis I }\end{array}$ & $\begin{array}{l}\text { Third } \\
\text { Intermediate } \\
\text { Period, } 25^{\text {th }} \\
\text { Dynasty }\end{array}$ & $\begin{array}{l}\text { The Egyptian } \\
\text { museum at Cairo } \\
\text { (CG 42199). }\end{array}$ & $\begin{array}{c}\text { God/ } \\
\text { husband }\end{array}$ & $\begin{array}{l}\text { King of the gods } \\
\text { who is in the middle } \\
\text { of the Ennead of } \\
\text { gods. }\end{array}$ & Wife & Sideways \\
\hline
\end{tabular}

(Designed by the Researcher) 
According to the previous table the number of the scenes and statues represent the motif of sitting on a man's lap is sixteen. No depictions for the motif appeared during the Old Kingdom period neither in scenes nor statuary, in spite of the early mention of the expression sitting on his father's lap in the Pyramid Texts (PT 553 §1367c).

The earliest representation for the motif in scenes is the $12^{\text {th }}$ Dynasty scene of Dedusobek and his daughter, while the earliest one in statuary is the $18^{\text {th }}$ dynasty private statue of the tutor Senmen with princess Neferure.

The motif of lap sitting includes four main classifications according to the identity of the seated man; sitting on father's lap, sitting on tutor's lap, sitting on a kneeling worshipper's lap, and sitting on husband's lap. The more depicted one is the motif of sitting on tutor's lap.

The main context of the scenes that included the motif of sitting on a man's lap is receiving offerings from other members of the family of the main figure of the motif.

The interactions between the two depicted individuals in the motif of lap sitting is clearly reflected in scenes than statuary. The characteristic gestures for expressing the affection of a child when the main figure of the motif is a tutor are:

- Placing gently one hand of the royal child on the shoulder or the chest of the tutor.

- Presenting a lotus blossom to the nose of the tutor (scene of the tutor Horemhab).

- Presenting a type of fruit to the mouth of the child (scene of Horemhab).

There are certain characteristic gestures for expressing protection towards the child in scenes and statuary that may denote the young age of the child and his need for further care:

- Embracing the royal child from the back with both hands. This gesture appeared for the first time in the motif of sitting on a father's lap in the Middle Kingdom private scene of Dedusobek and his daughter, where one hand appear hiding beneath the other on the waist of the child girl. The same gesture was represented in statuary in the $18^{\text {th }}$ Dynasty statues of the tutors Senenmut and Sobekhotep, but the hands were placed vertically beside each other on the torso of the royal child for more protection.

- Touching gently with the right hand the back of the child's head. This gesture appeared in three $18^{\text {th }}$ Dynasty scenes of the tutors Pahery, Min, and Meryre. 
- Holding completely with one hand the waist of the child in the scene of the tutor Meryre.

- Functioning the natural human back rest in statuary for protecting the back of the child instead of the carved back pillar. This natural back rest is represented in two ways; raising usually the left knee when the child is sitting sideways (statues of the tutors Senmen and Senenmut), and using the torso (the area directly beneath the chin) as a rest for the back of the child in case of sitting facing forward (statues of the tutors Senenmut and Sobekhotep).

- Enveloping completely the child's body in the tutor's mantle. This gesture appeared once in the $18^{\text {th }}$ Dynasty statue of Senenmut with Neferure.

Concerning the secondary figure, the child, in the motif of sitting on the lap of a father or a tutor, the characteristic features of childhood as indicated in the two signs in Gardiner's sign list (A 17) and appeared in the scenes and statuary are:

- Representing nude except for four cases; wearing a short kilt in the statue of Siptah and his unknown father, the scene of the tutor Meryre, and the statue of the tutor Sobekhotep, and wearing all the royal costumes of a king in the scene of the tutor Hekareshu.

Sometimes the nude child is represented wearing certain objects for protection or decoration: an amulet as in the scene of the tutor Pahery, jewelry (necklaces, armlets, bracelets, and anklets) as in the scene of TT 226, and a crown and sandals as in the scene of the tutor Horemhab.

- Representing with a single lock of hair that was depicted in various forms; a back pigtail for girl or a massive side lock, a side braided plait of hair, a thin side lock of hair, and a long wide side lock of hair. The more depicted forms are the side braided plait of hair, and the thin side lock of hair.

- Holding the index finger to the mouth that is only appeared in the statues of the tutor Senenmut with princess Neferure.

The child sitting on the lap of either a father or a tutor in most of the scenes and statuary is usually a boy, except for six cases for a child girl; three in scenes (the scene of Dedusobek, the scene of Thener, and the scene of Horemhab), and three in statuary (the statues of Neferure with her tutors Senmen and Senenmut).

Unique representations and attitudes in the motif of sitting on a man's lap:

- All scenes and statuary represent just one individual sitting on the lap except for the $18^{\text {th }}$ Dynasty scene of TT 226 that shows four children sitting on the lap of a man (tutor). The children are arranged on the lap by their tallness. The child that is close to the chest of his tutor is the 
tallest one. Such number of children on a lap of a tutor denote the long serving tutor to comprise all the children, whom he had the honor to educate.

- The traditional pose of the scribe was once represented in the motif of lap sitting in the $18^{\text {th }}$ Dynasty statue of Sobekhotep.

- All the scenes represent the main figure, the seated man, sitting on a high or low backed chair except for the $18^{\text {th }}$ Dynasty scene of Horemhab, where the tutor is shown sitting on a folding stool.

- The unique partly damaged royal scene of king Akhenaten in expressing the intimacy and strong bonding between the three main members of a family (the husband, the wife, and the children) by gathering and arranging them in a single motif (lap sitting): the wife on the lap of her husband, while the children on the lap of their mother. Such use of innovated ways in expressing a certain idea is typical in the scenes of Tel el-Amarna.

- The unique facial and hand gestures in the unfinished royal couple statue of Akhenaten reflect clearly the sexual intimacy and interaction between the man and woman in ancient Egypt.

- The unique $25^{\text {th }}$ Dynasty royal and divine partly damaged couple statue of god Amun and the expressing of the divine protection and care towards his divine wife that appears in the hand gesture being clenched together on her waist.

\section{REFERENCES}

- Abd El Ghafar Shadeed, Maqaber Bani Hassan fi Masr Al Wasta, First Edition, (Cairo: Al Markez Al Qawme lltargma, 2016).

- Adela Oppenheim, Dorothea Arnold, Dieter Arnold, and Kei Yamamoto, Ancient Egypt Transformed the Middle Kingdom, (New York: the Metropolitan Museum of Art, 2015).

- Aidan Dodson and Jac. J. Janssen, "A Theban Tomb and Its Tenants", in JEA 75, (1989).

- Aidan Dodson, "The Problem of Amenirdis II and the Heirs to the Office of God's Wife of Amun during the Twenty-Sixth Dynasty", in JEA 88, (2002).

- Alessandro Bongioanni and Maria Sole Croce, The Treasures of Ancient Egypt from the Egyptian Museum in Cairo, (Rizzoli, 2003).

- Anne K. Capel, Glenn Markoe, and Betsy M. Bryan, Mistress of the House Mistress of Heaven Women in Ancient Egypt, (New York: Hudson Hills press, 1996). 
- Annelies and Artur Brack, "Das Grab des Haremheb, Theben Nr. 78", in Archäologische Veröffentlichungen 35, (Mainz am Rhein: Verlag Philipp von Zabern, 1980).

- Arielle P. Kozloff, Amenhotep III: Egypt's Radiant Pharaoh, (Cambridge University Press, 2012).

- Arlette David, "A Throne for Two: Image of the Divine Couple during Akhenaten's Reign", in Journal of Ancient Egyptian Interconnections, http://jaei.library.arizona.edu, Vol. 14 (June 2017).

- B. van de Walle، "Precisions Nouvelles sur Sobek-hotep Fils de Min", in $R d E 15$ (1963).

- Barry Kemp, 100 Hieroglyphs: Think Like An Egyptian, (Granta Books, 2012).

- Bernard V. Bothmer, "Private Sculpture of Dynasty XVIII in Brooklyn", in The Brooklyn Museum Annual 8, (1966).

- Betsy Bryan, "Property and the God's Wives of Amun", in Women and property in ancient Near Eastern and Mediterranean societies, conference organizers and editors Deborah Lyons and Raymond Westbrook, (Cambridge: Harvard Center for Hellenic Studies, 2003).

- Betsy M. Bryan, The Reign of Thutmose IV, (Baltimore and London: The Johns Hopkins University Press, 1991).

- Boyo Ockinga and Susanne Binder, "Fragments of an Amarna-age Stele in the Teti Pyramid Cemetery North", in Études et Travaux XXVI, (2013).

- Brian Alm, Thutmose IV, in NILE Magazine, No.12, (2018).

- C.H. Roehrig, "The Statue of the Royal Nurse Sitre with her Nursling Maatkare Hatshepsut", in M. Eldamaty, M. Trad (éd.), Egyptian Museum Collections around the World. Studies for the Centennial of the Egyptian Museum, II, (Cairo 2002).

- Catalogue général des antiquités égyptiennes du musée du Caire Nos 42192- 42250, Statues et statuettes de rois et de particuliers III, (Cairo: IFAO, 1914).

- Catharine H. Roehrig, Renée Dreyfus, Cathleen A. Keller, Hatshepsut from Queen to Pharaoh, (Metropolitan Museum of Art, 2005).

- Catharine Hershey Roehrig, the Eighteenth Dynasty titles royal nurse (mnt nswt), royal tutor (mn' nswt), and foster brother/sister of the Lord of the Two Lands (sn/snt mn' n nb t3wy), Ph.D., (Berkeley: University of California, 1990).

- Cristina Pino Fernández, "Una Posible Damnatto Memoriae Dethutmose IV en Tebas", in BAEDE Boletín de la Asociación Española de Egiptología, núm. 24, (2015).

- Cyril Aldred, "The Parentage of King Siptah", in JEA 49, (1963). 
- Cyril Aldred, New Kingdom Art in Ancient Egypt during the Eighteenth Dynasty 1570 to 1320 B.C., (Londres, 1961).

- Danijela Stefanović, "The Stela of Dedusobek. (Cairo, CG 20596)", in Zeitschrift für Ägyptische Sprache und Altertumskunde, Volume 136 Issue 1, (2009).

- David Berg, "The Vienna Stela of Meryre", in The Journal of Egyptian Archaeology, Vol. 73 (1987).

- David O'Connor and Eric H. Cline, Amenhotep III Perspectives on His Reign, (United States of America: University of Michigan Press, 2001).

- Dina Metawi, "The Stela of the Outline Draftsman Tnr and His Family (Cairo Museum JE 18924)", in Journal of Near Eastern Studies 77, no. 1 (2018).

- Dominic Montserrat, Akhenaten: History, Fantasy and Ancient Egypt, (New York: Routledge, 2014).

- Dorothea Arnold, The Royal Women of Amarna: Images of Beauty from Ancient Egypt (New York: Metropolitan Museum of Art, 1996).

- E. R. Russmann, Eternal Egypt: Masterworks of Ancient Art from the British Museum, (London, 2001).

- Edith Bernhauer, Innovationen in der Privatplastik. Die 18. Dynastie und ihre Entwicklung, Philippika 27, (Wiesbaden 2010).

- Erika Feucht, "Childhood", in Donald B. Redford (Hrsg.), The Oxford Encyclopedia of Ancient Egypt, Band 1, (Oxford 2001).

- Gabriele Pieke, "Der Grabherr und die LotosblumeZu lokalen und geschlechtsspezifischen Traditioneneines Motivkreises", in Miroslav Bárta, the Old Kingdom Art and Archaeology, Proceedings of the Conference held in Prague May 31-June 4, 2004, (Czech Institute of Egyptology, Faculty of Arts, Charles University in Prague, 2006).

- Gae Callender, "The Cripple, the Queen \& the Man from the North", in KMT 17, No.1 (2006).

- Galal Ali Hassaan, Mechanical Engineering in Ancient Egypt, Part II: Jewellery Industry (Pectorals), in International Journal of Recent Engineering Science (IJRES), volume 3 Issue 1, (2016).

- Georges Legrain, "Sur un groupe d'Amon et d'Améniritis I", in Recueil deTravaux 31 (1909).

- Georges Legrain, Statues et statuettes de rois et de particuliers, Catalogue général des antiquités égyptiennes du Musée du Caire, Vol. I, (Cairo: l'Institut français d'archéologie orientale, 1906).

- Gerry D. Scott, The History and Development of the Ancient Egyptian Scribe Statue, (Yale University, 1989).

- H. Frankfort, Heresy in a Theocratic State, in Journal of the Warburg and Courtauld Institutes, Vol. 21 No.3/4, (1958). 
- H. Jacquet-Gordon, "Concerning a Statue of Senenmut", in BIFAO 71, (1972).

- H. R. Hall, "The Statues of Sennemut and Menkheperresenb in the British Museum", in JEA 14, (1928).

- H. R. Hall, Hieroglyphic texts from Egyptian stelae, etc., in the British Museum, Part 5, (London, 1914).

- J. Capart, "Une Statue de Sebekhotep, Precepteur Royal", in Bulletin des Musees Royaux d'Art et d'Histoire, No. 4, (1938).

- J. J. Tylor and F. Ll. Griffith, The Tomb of Paheri at El Kab, (London: Egypt exploration fund, 1895).

- J. Von Beckerath, Queen Twosre as Guardian of Siptah, in JEA 48, (1962).

- J.E. Harris and E.F. Wente, An X-Ray Atlas of the Royal Mummies, (Chicago, 1980).

- James K. Thomson, "A First Acolyte of Amun", in The Journal of Egyptian Archaeology 84, (1998).

- James P. Allen, A New Concordance of the Pyramid Texts, Volume I, (Providence: Brown University, 2013).

- Jennifer Witts, The role of magic and medicine in the lives of ancient Egyptian women and their children, MPhil Thesis, (University of Stellenbosch, 2005).

- John Ashton and David Down, Unwrapping the Pharaohs, (China, 2006).

- Jürgen von Beckerath, Chronologie des Pharaonischen Ägypten, in MÄS 46 (Mainz: Philipp von Zabern, 1997).

- Kasia Szpakowska, Daily Life in Ancient Egypt, (Wiley, 2007).

- Kazimierz Michalowski, L'art de l'Égypte ancienne (Nouvelle édition revue et augmentée par Jean-Pierre Corteggiani et Alessandro Roccati), (Paris, 1994).

- Labib Habachi, "Tomb No 226 of the Theban Necropolis and its Unknown Owner", in W. Helck (Ed.), Festschrift für Siegfried Schott zu seinem 70. Geburtstag, (Wiesbaden 1968).

- Manal B. Hammad, The Statuette Group of God Amun and Amenirdis I Cairo Museum (CG 42199), in Journal of Association of Arab Universities for Tourism and Hospitality (JAAUTH), Vol. 17 No. 1, (2019).

- Marwa Elkady, Manal Mahmoud and Nermin Gad , "Wet Nurse in art in Graeco-Roman Egypt", in Journal of the Faculty of Tourism and Hotels, Alexandria University, Vol. 16, Issue 2, (2019).

- Matthew F. Petrie, Tell el Amarna (London:Methuen, 1894). 
- Megaera C. Lorenz, the Role of Male Royal Offspring in 18th Dynasty Egypt, A Dissertation Submitted to the Faculty of the Division of the Humanities in Candidacy for the Degree of Doctor of Philosophy, the University of Chicago, (Chicago, Illinois, 2017).

- N. De G. Davies, The Tomb of Neferhotep at Thebes II, (New York, 1933).

- Norman de Garis Davies, "The tomb of Senmen, brother of Senmut", in Proceedings of the Society of Biblical Archooology 35, (1913).

- Norman de Garis Davies, "The Graphic Work of the Expedition", in the Metropolitan Museum of Art Bulletin 18, (1923).

- P. Virey, Sept tombeaux thébains, in MMAF 2, (1889).

- Percy E. Newberry, The Sons of Tuthmosis IV, in The Journal of Egyptian Archaeology, Vol. 14, No. 1/2 (1928).

- Rebecca Clifton, Art and Identity in the Age of Akhenaten, PhD Thesis, the School of Historical and Philosophical Sciences at the University of Melbourne, (2019).

- Rehab Elsharnouby, "Statue Attributes of the Old Kingdom Queens", in International Journal of Heritage, Tourism and Hospitality Vol.12, No. 2/2, (2018).

- Richard H. Wilkinson, Reading Egyptian Art, (London: Thames and Hudson, 1992).

- Suzanne Ratié, "Attributs et destinée de la princesse Neferoure", in Bulletin de la Société d'Égyptologie, Genève 4, (1980)

- The Egyptian Museum, Splendors of ancient Egypt, (Cairo, BoothClibborn Editions, 1996).

- W. el-Saddik, Die Konigsfamilie in der Kunst der Amarnazeit. In C. Tietze \& E. Hornung (Eds.), Amarna. Lebensräume - Lebensbilder Weltbilter, Austellungskatalog Echnaton und Amarna, Ägypten im neuen Licht, 6. September 2010 bis 30. Januar 2011im Gustav-Lübcke Museum der Stadt Hamm, (Weimar: Arcus-Verlag, 2010).

- William Kelly Simpson, "Egyptian Sculpture and Two-Dimensional Representation as Propaganda", in The Journal of Egyptian Archaeology, Volume 68 issue 1, (1982).

- Z. Hawass, and M. Maher Taha, Le tombeau de Menna, (Cairo, 2002). 